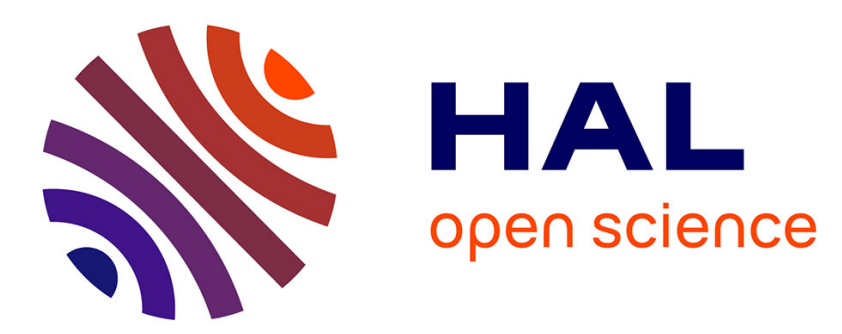

\title{
Prediction of surface and "under surface" temperatures on poultry muscles and poultry skins subjected to jets of superheated steam
}

\author{
Alain Kondjoyan, Stéphane S. Portanguen
}

\section{- To cite this version:}

Alain Kondjoyan, Stéphane S. Portanguen. Prediction of surface and "under surface" temperatures on poultry muscles and poultry skins subjected to jets of superheated steam. Food Research International, 2010, 41 (1), pp.16-30. 10.1016/j.foodres.2007.07.006 . hal-02923858

\section{HAL Id: hal-02923858 \\ https://hal.inrae.fr/hal-02923858}

Submitted on 27 Aug 2020

HAL is a multi-disciplinary open access archive for the deposit and dissemination of scientific research documents, whether they are published or not. The documents may come from teaching and research institutions in France or abroad, or from public or private research centers.
L'archive ouverte pluridisciplinaire HAL, est destinée au dépôt et à la diffusion de documents scientifiques de niveau recherche, publiés ou non, émanant des établissements d'enseignement et de recherche français ou étrangers, des laboratoires publics ou privés. 


\title{
Prediction of surface and "under surface" temperatures on poultry muscles and poultry skins subjected to jets of superheated steam
}

\author{
Alain Kondjoyan *, Stéphane Portanguen \\ INRA, UR370 Qualité des Produits Animaux, F-63122 St. Genès Champanelle, France \\ Received 15 March 2007; accepted 29 July 2007
}

\begin{abstract}
An apparatus was designed and built to apply short, homogeneous and controlled superheated steam treatments at the surface of solid products. Experiments were carried out on Teflon ${ }^{\circledR}$ and poultry samples. The treatment which uses a jet of superheated steam can be broken down in four steps: (1) initial steam condensation, (2) evaporation of condensates, (3) convective heating in superheated steam, (4) final air-cooling of the surface. A transfer model was developed to analyse and predict experimental results based on assumptions of film condensation and film evaporation. Good agreement was found between calculated and experimental results obtained on Teflon ${ }^{\circledR}$ for the highest jet temperatures. For lower jet temperatures, the model has to be adjusted to mimic droplet evaporation. When applied to poultry, the model requires adjustments due to complex cooking-related phenomena.
\end{abstract}

(C) 2007 Elsevier Ltd. All rights reserved.

Keywords: Transfer; Temperature; Decontamination; Superheated; Steam; Poultry

\section{Introduction}

Superheated steam is commonly used for drying biological or non-biological products, including foods (Braud, Moreira, \& Castell-Perez, 2001; Moreira, 2001; Taechapairoj, Prachayawarakorn, \& Soponronnarit, 2006), wood chips (Fyhr \& Rasmuson, 1997) or coal (Chen, Wu, \& Agarwal, 2000). Drying by superheated steam lasts at least a few dozen minutes and is usually restricted to gas temperatures below $250^{\circ} \mathrm{C}$. Modelling research thus far has focussed on the variations of water diffusivity in the product and the consequences in terms of water losses (Braud et al., 2001; Chen et al., 2000; Fyhr \& Rasmuson, 1997; Taechapairoj et al., 2006). The first minute of treatment when steam condenses at the surface of product and then evaporates is usually not studied, and temperature predictions are only validated by measurements inside the product. However short superheated steam treatments can be

\footnotetext{
* Corresponding author. Tel.: +33 0473624492; fax: +33 0473624089.

E-mail address: alain.kondjoyan@clermont.inra.fr (A. Kondjoyan).
}

thought up to modify the properties at the surface of food products as for example to "roast" a piece of meat at the end of its microwave cooking. In present paper the superheated treatment is dedicated to the bacterial decontamination of the surface of poultry products. Steam could inactivate bacteria more efficiently than hot air, although this inactivation remained limited (James \& Evans, 2006; McCann, Sheridan, McDowell, \& Blair, 2006). Inactivation of bacteria by superheated steam is studied rarely, or under steam conditions below $150{ }^{\circ} \mathrm{C}$ (Spicher, Peters, Nürnberg, \& Schwebke, 2002). Thus the idea is to work with highest superheated steam temperatures and short durations to increase the microbial inactivation while limiting the deterioration of the food product. It is not worthy to discuss about the thermal inactivation of micro-organisms without an accurate knowledge of the temperature at the surface and just under the surface of the product. This paper aims at analysing the evolution of these temperatures during thermal treatment (Microbial measurements will be given in a next paper).

During the first minute of a superheated steam treatment the very rapid rise in surface temperature is strongly 


\begin{tabular}{|c|c|c|c|}
\hline \multicolumn{4}{|c|}{ Notation } \\
\hline \multicolumn{2}{|c|}{ Latin symbols } & \multirow{2}{*}{$\begin{array}{l}\operatorname{Re} \\
r\end{array}$} & \multirow{2}{*}{$\begin{array}{l}\text { Reynolds number equal to } V \cdot D / v \\
\text { distance from the stagnation point of the } \\
\text { impinging jet }(\mathrm{m})\end{array}$} \\
\hline$C_{\mathrm{p}}$ & $\begin{array}{l}\text { specific heat of gas under constant pressure con- } \\
\text { ditions }\left(\mathrm{J} \mathrm{kg}^{-1} \mathrm{~K}^{-1}\right)\end{array}$ & & \\
\hline$C_{\mathrm{v}}$ & $\begin{array}{l}\text { specific heat of gas under constant volume con- } \\
\text { ditions }\left(\mathrm{J} \mathrm{kg}^{-1} \mathrm{~K}^{-1}\right)\end{array}$ & $T_{\text {bottom }}$ & $\begin{array}{l}\text { temperature of sample support }\left({ }^{\circ} \mathrm{C} \text { or } \mathrm{K}\right) \\
\text { calibrated temperature measured by the IR sen- }\end{array}$ \\
\hline$D$ & diameter of pipe outlet (outlet of the jet) (m) & $I_{\text {cor }}$ & $\begin{array}{l}\text { calibrated temperature measured by the } 1 \mathrm{~K} \text { sen- } \\
\text { sor }\left({ }^{\circ} \mathrm{C} \text { or } \mathrm{K}\right)\end{array}$ \\
\hline$D_{\mathrm{t}}$ & thermal diffusivity of sample $\left(\mathrm{m}^{2} \mathrm{~s}^{-1}\right)$ & $T_{\mathrm{eb}}$ & boiling temperature of water $\left({ }^{\circ} \mathrm{C}\right.$ or $\left.\mathrm{K}\right)$ \\
\hline$H$ & distance between jet and impinged surface $(\mathrm{m})$ & $T_{\mathrm{ir}}$ & temperature measured by the non-calibrated IR \\
\hline$\Delta H$ & $\begin{array}{l}\text { Energy of evaporation or condensation of water } \\
\left(\mathrm{J} \mathrm{kg}^{-1}\right)\end{array}$ & $T_{\mathrm{m}}$ & $\begin{array}{l}\text { pyrometer }\left({ }^{\circ} \mathrm{C} \text { or } \mathrm{K}\right) \\
\text { medium temperature }\left({ }^{\circ} \mathrm{C} \text { or } \mathrm{K}\right)\end{array}$ \\
\hline$h_{\text {bottom }}$ & $\begin{array}{l}\text { transfer coefficient used for conduction on the } \\
\text { downside of samples }\left(\mathrm{W} \mathrm{m}^{-2} \mathrm{~K}^{-1}\right)\end{array}$ & & $\begin{array}{l}\text { product surface temperature }\left({ }^{\circ} \mathrm{C} \text { or } \mathrm{K}\right) \\
\text { temperature of superheated steam jet }\left({ }^{\circ} \mathrm{C} \text { or } \mathrm{K}\right)\end{array}$ \\
\hline$h_{\text {cool }}$ & $\begin{array}{l}\text { convective or effective transfer coefficient during } \\
\text { air cooling }\left(\mathrm{W} \mathrm{m}^{-2} \mathrm{~K}^{-1}\right)\end{array}$ & & $\begin{array}{l}\text { time }(\mathrm{s}) \\
\text { distance inside product from surface }(\mathrm{m})\end{array}$ \\
\hline$h_{\mathrm{eb}}$ & $\begin{array}{l}\text { transfer coefficient used to determine evapora- } \\
\text { tion of condensates }\left(\mathrm{W} \mathrm{m}^{-2} \mathrm{~K}^{-1}\right)\end{array}$ & V & jet velocity $\mathrm{m} \mathrm{s}^{-1}$ \\
\hline$h_{\text {eff }}$ & effective heat transfer coefficient $\left(\mathrm{W} \mathrm{m}^{-2} \mathrm{~K}^{-1}\right)$ & \multicolumn{2}{|c|}{ Greek symbols } \\
\hline$h^{t}$ & value of $h_{\text {cond }}$ or $h_{\mathrm{eb}}$ at time $t\left(\mathrm{~W} \mathrm{~m}^{-2} \mathrm{~K}^{-1}\right)$ & $\lambda$ & product thermal conductivity $\left(\mathrm{W} \mathrm{m}^{-1} \mathrm{~K}^{-1}\right.$ ) \\
\hline$h_{\text {conv }}$ & $\begin{array}{l}\text { convective or effective transfer coefficient during } \\
\text { the last heating period }\left(\mathrm{W} \mathrm{m}^{-2} \mathrm{~K}^{-1}\right)\end{array}$ & $\lambda_{\mathrm{g}}$ & $\begin{array}{l}\text { gas (air or superheated steam) thermal conduc- } \\
\text { tivity }\left(\mathrm{W} \mathrm{m}^{-1} \mathrm{~K}^{-1} \text { ) }\right.\end{array}$ \\
\hline$h_{\text {cond }}$ & $\begin{array}{l}\text { transfer coefficient for steam condensation } \\
\left(\mathrm{W} \mathrm{m} \mathrm{K}^{-2} \mathrm{~K}^{-1}\right)\end{array}$ & $\begin{array}{l}\lambda_{\text {water }} \\
v\end{array}$ & $\begin{array}{l}\text { thermal conductivity of water }\left(\mathrm{W} \mathrm{m}^{-1} \mathrm{~K}^{-1}\right) \\
\text { gas (air or superheated steam) viscosity }\left(\mathrm{m}^{2} \mathrm{~s}^{-1}\right)\end{array}$ \\
\hline $\begin{array}{l}\delta_{\text {film }} \\
\delta t\end{array}$ & $\begin{array}{l}\text { thickness of the condensation film }(\mathrm{m}) \\
\text { time step used for numerical calculations (s) }\end{array}$ & $\rho_{\mathrm{atm}}$ & $\begin{array}{l}\text { density of the gas (air or superheated steam) un- } \\
\text { der atmospheric pressure }\left(\mathrm{kg} \mathrm{m}^{-3}\right)\end{array}$ \\
\hline$\Delta H$ & latent heat of water evaporation $\left(\mathrm{J} \mathrm{kg}^{-1}\right)$ & $\rho_{\mathrm{p}}$ & density of the gas (air or superheated steam) un- \\
\hline$N u$ & Nusselt number equal to $h_{\text {conv }}$ (or $\left.h_{\text {cool }}\right) \cdot D / \lambda_{\mathrm{g}}$ & & der pressure $P\left(\mathrm{~kg} \mathrm{~m}^{-3}\right)$ \\
\hline $\begin{array}{l}P_{\text {atm }} \\
P\end{array}$ & $\begin{array}{l}\text { atmospheric pressure }(\mathrm{Pa} \text { or } \mathrm{mm} \text { of } \mathrm{Hg}) \\
\text { pressure }(\mathrm{Pa})\end{array}$ & $\rho_{\text {water }}$ & density of water $\left(\mathrm{kg} \mathrm{m}^{-3}\right)$ \\
\hline
\end{tabular}

affected by steam condensation and further evaporation of condensates.

There are three main steps during the first minutes of surface-heating by superheated steam: (1) an initial steam condensation step that leads to a very rapid rise in temperature and an increase of water condensates; (2) when surface temperature reaches the water boiling temperature, condensates begin to evaporate and their temperature remains constant until they disappear; (3) afterwards, the surface temperature increases due to the convection of superheated steam, although the rate of temperature increase can be slowed down by the evaporation of water coming from the product.

Heat transfer in impinging jets of pure gas has been extensively studied and is known to be dependent on the shape of the nozzle exit (Martin, 1977). Condensation and evaporation of droplets or water layers are highly dependent on the wettability of the surface, which greatly affects heat flux during phase change (Gokhale, Plawsky, \& Wayner, 2003; Grandas, Reynaed, Santini, \& Tadrist, 2005; Kim \& Kang, 2003). To our knowledge, detailed analysis of the condensation of superheated steam on a plate has only been performed for laminar flows parallel to a flat plate (Kang \& Kim, 1999). The phenomena involved are complex and are highly dependent on process configuration and the nature of product surface. Detailed modelling of these phenomena is beyond the scope of this paper, which aims at developing a usable model for food microbiologists and engineers applying a simplified approach based on the assumption of film condensation and evaporation. This approach is validated on samples made of Teflon ${ }^{\circledR}$ and afterwards on poultry meat either covered or not covered by skin. The thermal properties of Teflon ${ }^{\circledR}$ are close to those of poultry meat, but Teflon ${ }^{\circledR}$ is not an evaporating product and it has the advantage of being more stable than meat when subjected to high temperatures.

\section{Experimental device}

\subsection{Description}

An apparatus was designed to provide homogenous steam decontamination treatments on small solid samples. Requirements were the possibility of setting different temperatures for the superheated steam and the ability to continuously measure sample surface temperature throughout the treatment process. 

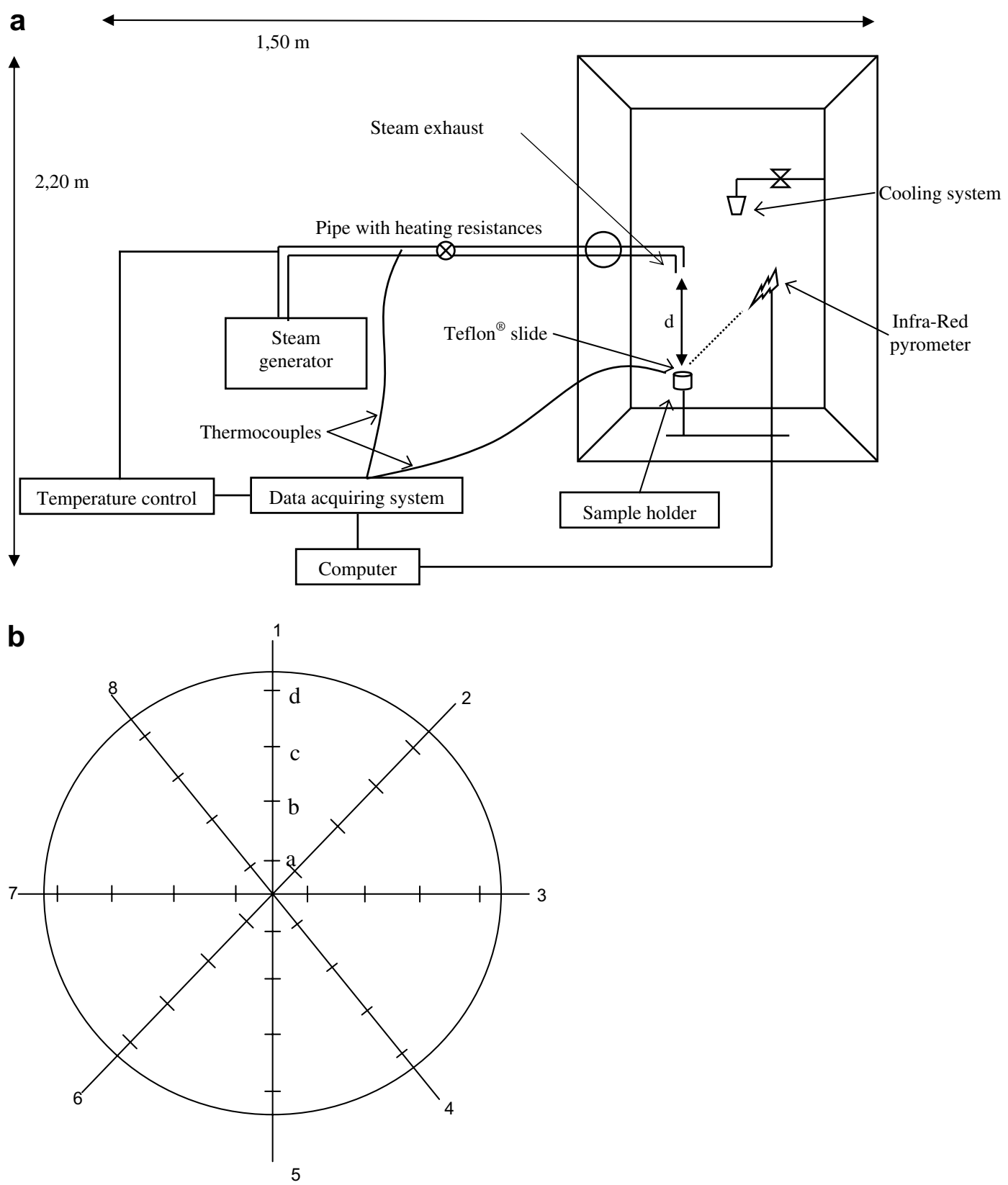

Fig. 1. (a) Schematic representation of the functioning of the superheated steam rig; (b) target used to measure local variations in velocity and temperature inside the impinging jet.

Steam was produced by a generator operating under 57 bars of pressure. Steam produced from the generator at $150-165^{\circ} \mathrm{C}$ was released into a stainless steel pipe channelling the steam to the sample (Fig. 1a). The pipe of $21 \mathrm{~mm}$ in internal diameter and $3 \mathrm{~mm}$ in thickness was surrounded by two electrical resistances of $75 \mathrm{Ohms}$ each and insulated by more than $100 \mathrm{~mm}$ of rock wool, which can withstand temperatures of up to $1000{ }^{\circ} \mathrm{C}$. Superheated steam was produced by the action of the electrical resistances heating the pipe. A straight pipe section was then bent in such as way that the outlet was located just above the sample surface. The distance between pipe bend and pipe outlet was $460 \mathrm{~mm}$. As the steam jet was released into the air, the steam mixed with the air before impinging on the sample surface. The further the sample surface was held from the outlet of the pipe, the more air was allowed into the mixture and the cooler that mixture. Since the jet cools as its air content increases, then a further distance $d$ from the pipe outlet did not inevitably lead to a dryer mixture (Fig. 1a).

The sample was located in a hollow cylindrical support made of Teflon ${ }^{\circledR}$. The sample was made of either poultry meat covered or not covered by skin, or of Teflon ${ }^{\circledR}$. Polytetrafluoroethylene, better known as Teflon ${ }^{\circledR}$, is a non-biological, hydrophobic, thermal-resistant surface whose thermal characteristics were found to be close to those of 
meat products (Kondjoyan, McCann et al., 2006; Kondjoyan, Rouaud et al., 2006). The different samples used during the experiments were: (1) short Teflon ${ }^{\circledR}$ cylinders $5 \mathrm{~cm}$ in diameter and $2 \mathrm{~cm}$ in thickness, (2) circular slides of Teflon ${ }^{\circledR} 5 \mathrm{~cm}$ in diameter and $1 \mathrm{~mm}$ in thickness, (3) poultry meat samples, either covered or not covered by skin, similar in dimensions to the short Teflon ${ }^{\circledR}$ cylinders, and (4) large strips of poultry skin. Thickness of poultry skin was measured before each experiment. The skin was placed between two flat plastic plates of a precisely determined thickness. Thickness of skin was measured with an accuracy of $\pm 0.1 \mathrm{~mm}$, but as the strip of skin was not uniform the measurement only gave an average value of its thickness. Before the thermal experiments, the sample surface was positioned flush to the surface of the support. Distance $d$ between the sample surface and the pipe outlet can be very accurately set using a manual traversing system, and for these experiments the distance $d$ was set at $36 \mathrm{~mm}$. Sample and support were positioned on a sliding device mounted on a ball bearing system. The temperature at the sample surface was measured using an Infra-Red thermometer over a spot of $2 \mathrm{~cm}$ in diameter located at the centre of sample. The digital IR pyrometer (IN 500, Impact system) was sensitive to IR radiations between $8 \mu \mathrm{m}$ and $14 \mu \mathrm{m}$, and its accuracy as given by the manufacturer was $1-1.8 \%$ of the nominal value in the range $0-300{ }^{\circ} \mathrm{C}$. The temperature of the IR sensor was maintained constant throughout the treatment so as to avoid electronic drift. Acquisition frequency of the Infra-Red system was $0.18 \mathrm{~s}$. The measuring part of the Infra-Red system was attached to the sliding device to be able to measure the sample surface temperature throughout the thermal treatment. The external temperature of the pipe was recorded using a thermocouple directly welded onto its surface. This measurement was introduced in a PID system and used to control pipe temperature. The temperature of the impinging jet was measured every second using a $0.6 \mathrm{~mm}$-thick thermocouple (of type $\mathrm{K}$ ) positioned $3.0 \mathrm{~mm}$ above the middle of the sample surface. The thermocouple had to be sensitive enough to capture fast variations in steam temperature while remaining unaffected by droplets. Preliminary tests performed with a $2.3 \mathrm{~mm}$-thick thermocouple had shown that droplets which impacted the thermocouple affected its response. The thermocouple was calibrated using a reference PT100 probe and an oil bath regulated from $0{ }^{\circ} \mathrm{C}$ to $270{ }^{\circ} \mathrm{C}$. The difference between the values given by the PT100 and by the thermocouple increased with temperature, but remained limited, reaching about $0.4{ }^{\circ} \mathrm{C}$ at $100{ }^{\circ} \mathrm{C}$ and $3{ }^{\circ} \mathrm{C}$ at $270{ }^{\circ} \mathrm{C}$. Response of the thermocouple was calibrated using a linear regression.

Before each experiment, the axis of the pipe was centred at the middle of the sample surface. The measurement spot of the IR thermometer was centred at the same point using a laser beam. The generator was switched on, and the temperature of the heating pipe was set to obtain the desired temperature of the jet at the sample surface. The apparatus was kept under the same heating conditions for at least $2 \mathrm{~h}$ so as to reach steady-state conditions before the experiments began.

The sample was moved $30 \mathrm{~cm}$ away from the superheated steam jet, and steam was released during a few minutes to purge the system and to limit droplet formation in the jet. The sample was then slid beneath the jet. At the end of the heat treatment, the sample surface was rapidly cooled by sliding the sample beneath a $45-55 \mathrm{~m} \mathrm{~s}^{-1}$ jet flow of cold air (temperature $3-5{ }^{\circ} \mathrm{C}$ depending on ambient temperature). This cold air was produced by a Ranque-Hilsch tube ("vortex tube") having an outlet diameter of $7 \mathrm{~mm}$. The three positions of the sliding system, i.e. sample away from the superheated steam jet, sample subjected to jet, and sample subjected to cold air, were perfectly set using a blocking ball bearing system.

\section{Transfer modelling}

\subsection{Physical phenomena - equations}

For the sake of simplicity, the following description refers to the jet of superheated steam mixed with air simply as the "jet of steam" or "jet".

Heat transfers were considered to be of one dimension (1D), i.e. the product was assumed to be a flat plate of infinite length and width, with a bottom side lying down on a support and a top side subjected to jet flow. The onedimensional approach is fully justified by the fact that during a very rapid treatment the exchanges perpendicular to product thickness are negligible relative to those which occur in the thickness direction.

Heating of the sample surface progressed throughout the three periods previously mentioned: (1) initial steam condensation, (2) evaporation of condensates, and (3) heating of sample surface by convection. The last period of treatment was the rapid cooling of sample surface by the cold air jet.

The evolution of temperature, $T$, with time, $t$, inside the product due to conduction was described by the heat diffusion equation (Fourier's second law), which is linear and parabolic in 1D:

$\frac{\partial T(x, t)}{\partial t}=D_{\mathrm{t}} \frac{\partial^{2} T(x, t)}{\partial x^{2}}$

Exchanges by conduction between the downside surface of sample and support were described using Newton's law (2). At the upside sample surface, boundary conditions were also described by (2), except during evaporation of condensates

$\lambda\left(\frac{\partial T}{\partial x}\right)_{\mathrm{s}}=h_{\mathrm{eff}}\left(T_{\mathrm{m}}-T_{\mathrm{s}}\right)$

where $T_{\mathrm{m}}$ is the temperature of the medium, i.e. either the temperature of the jet (steam jet during heating, cold air jet during cooling) at the upside surface of the sample or the temperature of the support for the downside surface of 
the sample. $h_{\text {eff }}$ was an effective transfer coefficient which took into account the different types of exchanges taking place during the treatment.

Steam condensation was assumed to happen uniformly at the sample surface, thus leading to the formation of a film of water which thickens with time. As soon as surface temperature reached $T_{\text {eb }}$, the film evaporated until vanishing completely. Variations in film thickness during a time step $\delta t$ were calculated using the following relation:

$\Delta \delta_{\text {film }}^{t}=\delta_{\text {film }}^{t+1}-\delta_{\text {film }}^{t}=\varepsilon \frac{h^{t}\left(T_{\text {steam }}-T_{\mathrm{s}}\right)}{\rho_{\text {water }} \Delta H} \delta t$

with $\varepsilon$ being 1 during film condensation and -1 during film evaporation.

During the condensation process, the value of the transfer coefficient $h^{t}$ introduced in relation (2) decreased at each time step due to the increasing resistance of the film. It was calculated as

$h_{\text {cond }}^{t+1}=\frac{1}{\frac{1}{h_{\text {cond }}^{t}}+\frac{\Delta \delta_{\text {film }}^{t}}{\lambda_{\text {water }}}}$

The use of (4) required the selection of an initial value for the transfer coefficient $h_{\text {cond }}^{0}$.

During film evaporation, relation (2) was replaced by a Dirichlet boundary condition where $T_{\mathrm{s}}$ was kept constant and equal to $T_{\mathrm{eb}}$. Variation of film thickness was calculated from (3) using a constant value $h_{\mathrm{eb}}$ for $h^{t}$. Initial thickness of the film was taken as the thickness reached at the end of steam condensation. Evaporation finished when $\delta_{\text {film }}^{0}$ reached 0 .

During the convection heating and cooling periods, the upside boundary condition was described by (2) using constant values for $h_{\text {eff }}$ named $h_{\text {conv }}$ and $h_{\text {cool }}$, respectively. For the Teflon ${ }^{\circledR}$ sample, the $h_{\text {conv }}$ and $h_{\text {cool }}$ constants used were pure convective transfer coefficients. For the poultry meat or skin samples, $h_{\text {conv }}$ and $h_{\text {cool }}$ included evaporation and cooking-related phenomena. As jet temperature increased, the relative humidity of the superheated steam became very low, meaning the sample surface was likely to dry rapidly. Drying rate depended on the evolution of the water activity at the surface of the evaporating sample. Evaporation can be theoretically calculated by modelling water diffusion in the sample, as performed in a previous study (Kondjoyan, McCann et al., 2006; Kondjoyan, Rouaud et al., 2006). However, heated poultry meat covered by skin became a very complex material, since lipids are known to melt at low temperature (Arnaud, Relkin, Pina, \& Collignan, 2004). Water diffusivity and the sorption curve remain totally unknown in such complex materials, especially at high temperatures. Since there is no use in adding several totally unknown parameters to a model, it was decided not to model water diffusion inside poultry samples but to discuss the possible effect of evaporation by comparing surface temperatures measured on poultry and on Teflon ${ }^{\circledR}$. For the same reasons, water transfer was not modelled during the cooling of the sample surface.

\subsection{Numerical procedure - inlet parameters}

Equations were discretised by a finite difference method using the second-order numerical scheme of Crank-Nicolson which carries the advantages of being numerically stable and accurate. The details of the discretisation procedure are not given here but can be found in Ozisik (1994). The model was implemented using Matlab 7.0. A preliminary study showed that 150 mesh points were required inside the sample, whose thickness did not exceed $0.02 \mathrm{~m}$, in order to calculate evolutions in surface temperature with an accuracy of $0.5^{\circ} \mathrm{C}$. A procedure was developed to adjust the time step so that the variation of surface temperature never exceeded $0.5^{\circ} \mathrm{C}$ during one time step. The PC ( $2 \mathrm{GHz} / 512 \mathrm{Mb})$ running the transfer model required 1-2 minutes to calculate the temperature kinetics at the surface of samples for a 1 minute treatment.

The thermal properties of the Teflon ${ }^{\circledR}$ sample used during the experiments were identified as being within the range $20-60{ }^{\circ} \mathrm{C}$ based on a previous study: $\lambda=$ $0.23 \mathrm{~W} \mathrm{~m}^{-1} \mathrm{~K}^{-1}, \quad D_{\mathrm{T}}=1.04 \times 10^{-7} \mathrm{~m}^{2} \mathrm{~s}^{-1} \quad$ (Kondjoyan, McCann et al., 2006; Kondjoyan, Rouaud et al., 2006). The thermal properties of Teflon ${ }^{\circledR}$ were assumed to remain unchanged for higher temperatures.

The theoretical maximum of the initial transfer coefficient value for condensation would correspond to the situation of pure stream condensing on a dry surface. This theoretical maximum was assessed using Brownian molecular velocity as $10^{7} \mathrm{~W} \mathrm{~m}^{-2} \mathrm{~K}^{-1}$ for a $100{ }^{\circ} \mathrm{C}$ temperature difference between the steam jet and the dry surface. However, this theoretical value was of no use because thermal resistance increases tremendously as soon as a thin layer of water developed at the sample surface. During our preliminary simulations, the heat transfer coefficient value decreased from $10^{7} \mathrm{~W} \mathrm{~m}^{-2} \mathrm{~K}^{-1}$ to $15,000 \mathrm{~W} \mathrm{~m}^{-2} \mathrm{~K}^{-1}$ in less than $0.1 \mathrm{~s}$. The transfer coefficient values required to describe most real situations are much lower than 15,000 $\mathrm{W} \mathrm{m}{ }^{-2} \mathrm{~K}^{-1}$. Results obtained by Techasena and Flick (1995) in pure steam were correctly simulated using a transfer coefficient value of about $1000 \mathrm{~W} \mathrm{~m}^{-2} \mathrm{~K}^{-1}$. In the present study, steam was mixed with air, and thus should be less than $1000 \mathrm{~W} \mathrm{~m}^{-2} \mathrm{~K}^{-1}$.

The $h_{\mathrm{eb}}$ value determined the duration of condensate evaporation. The choice of $h_{\mathrm{eb}}$ was somehow connected to the choice of $h_{\text {cond }}^{0}$ as the latter affected the thickness of the water film to be evaporated afterwards. The film assumption was just introduced into the model as a simplification. In reality, condensates were droplets. Evaporation of droplets is studied in literature by dropping liquids on heated plates made of aluminium or covered by Teflon ${ }^{\circledR}$ (Grandas et al., 2005). Variations in droplet shape and size and droplet evaporation rate were compared between the two supports for different initial droplet dimensions. Tef$\operatorname{lon}^{\circledR}$ is hydrophobic and led to more complex and longer evaporation than aluminium. However, it was not possible to transpose these results to what occurred in a jet of superheated steam, and the literature report cited could not be 
used to assess $h_{\mathrm{eb}}$. Moreover, nothing was known about droplet formation and evaporation on poultry muscle or on skin, where effects due to hydrophobicity of the material were likely to be complicated by juices expelled by the melting of lipids, and other cooking-related phenomena.

For a jet of gas impinging on a very long flat plate, the heat transfer coefficient can be calculated by (Martin, 1977):

$$
\begin{aligned}
N u= & \frac{D}{r} \frac{1-1.1 D / r}{1+0.1(H / D-6) D / r} 1.36 \operatorname{Re}^{0.574} \operatorname{Pr}^{0.47} \\
& (2000<\operatorname{Re}<30,000)
\end{aligned}
$$

The Reynolds number is calculated from the mean flow velocity at the jet outlet. Relation (5) has been validated in the literature for distances from the stagnation point of at least 2.5 times the nozzle diameter.

It is very difficult to predict velocity in an impinging jet produced from gas expansion inside a pipe from a given pressure $P$ to the atmospheric pressure $P_{\text {atm }}$, and the prediction is highly dependent on pipe geometry and outlet shape. Average velocity can be assessed from the thermodynamic laws of an "instantaneous isenthalpic expansion" of a perfect gas in a pipe:

$$
V=\sqrt{2 \frac{\gamma}{\gamma-1}\left[\frac{P}{\rho_{\mathrm{p}}}-\frac{P_{\mathrm{atm}}}{\rho_{\mathrm{atm}}}\right]}
$$

where $P$ is the initial pressure of the gas before expansion, $\gamma$ is equal to $C_{\mathrm{p}} / C_{\mathrm{v}}$, and $\rho_{\mathrm{p}}$ and $\rho_{\mathrm{atm}}$ are the gas densities at $P$ and $P_{\text {atm }}$, respectively. Relation (6) describes a theoretical case and does not take into account the pressure drop that follows the beginning of expansion, nor other effects such as friction on pipe walls or turbulence.

Air velocities of $45-55 \mathrm{~m} \mathrm{~s}^{-1}$ measured at the outlet of the Ranque-Hilsch tube were lower than the values calculated from (6). Cold air velocity was only $7-8 \mathrm{~m} \mathrm{~s}^{-1}$ when the flow impinged the sample surface.

\section{Results}

\subsection{Analysis of the impinging jet of steam - IR pyrometer calibration}

Classical anemometers could not be used to measure flow velocity in a jet of superheated steam. A simple device was developed to gain an idea of the velocity distribution in the superheated steam jet impinging the sample surface. The steam generator was disconnected and replaced by an air compressor. Pressure at the outlet of the compressor circuit was regulated using an expansion valve. Initial pressure was set to 5.5 bars. At the beginning of the experiment, compressed air was released in the (unheated) pipe and impinged the sample. Pressure in the valve fell to 2.0-3.0 bars, and after a few seconds it remained stable (within \pm 0.4 bars). The tip of a hot-film anemometer (Model 8465, TSI, USA) was positioned 2-3 $\mathrm{mm}$ above
Table 1

Jet velocity $\left(\mathrm{m} \mathrm{s}^{-1}\right)$ measured $2-3 \mathrm{~mm}$ above the sample covered by the target and at the locations given by eight radius and four concentric circles (Fig. 1b)

\begin{tabular}{llllll}
\hline Radius/Circle & $a$ & $b$ & $c$ & $d$ & Average $a-d$ \\
\hline 1 & 19 & 30 & 46 & 50 & 36 \\
2 & 17 & 31 & 45 & 50 & 36 \\
3 & 19 & 22 & 23 & 24 & 22 \\
4 & 23 & 40 & 51 & 51 & 41 \\
5 & 23 & 38 & 48 & 49 & 40 \\
6 & 27 & 38 & 42 & 39 & 37 \\
7 & 19 & 24 & 23 & 18 & 21 \\
8 & 19 & 29 & 37 & 36 & 30 \\
Average 1-7 & 21 & 32 & 39 & 40 & \\
STD 1-7 & 3.3 & 6.7 & 10.9 & 12.9 & \\
\hline
\end{tabular}

The velocity values at each location were obtained when measurements had remained stable for more than $1 \mathrm{~min}$.

the surface of the Teflon ${ }^{\circledR}$ sample. A circular target which had the same diameter as the sample was placed at the surface of the Teflon ${ }^{\circledR}$ sample (Fig. 1b) and used to position the sensor. The results given in Table 1 are stable over more than 1 minute. Velocity increased from $19 \mathrm{~m} \mathrm{~s}^{-1}$ at the centre of the sample to $40 \mathrm{~m} \mathrm{~s}^{-1}$ near its edge. Velocity was also higher on the radiuses " 2 , 4", which were located on the longer side of the pipe bend, than on radiuses " 7,8 ", which were located on the shorter side of the bend. Theoretical mean air velocity was calculated from (6) using $\gamma=1.4$ and factoring in the ratio of the tube section to the pipe section. The theoretical value given by (6) was $28 \mathrm{~m} \mathrm{~s}^{-1}$ for $P=2$ bars and $39 \mathrm{~m} \mathrm{~s}^{-1}$ for $P=3$ bars, and was thus in accordance with the average of the values given in Table $1\left(33 \mathrm{~m} \mathrm{~s}^{-1}\right)$.

Before a set of thermal experiments were conducted, the external and internal temperatures of the heating pipe were the same and equal to the temperature setting of the control system. During the first treatment of an experimental set, the temperature of the steam at the pipe outlet was close to the external temperature of the tube. Afterwards, the flow of steam and condensates (due to the purging of the circuit upstream from the pipe) cooled the internal part of the pipe. Heating resistances were not powerful enough to keep the internal temperature of the pipe constant across an experimental set, even when the external temperature of the pipe was close to the control temperature. Differences between external and internal temperatures increased with the number of consecutive experiments as well as with superheating temperature. Fig. 2 illustrates an example of temperatures recorded during the last experiment of a large experimental set where control temperature was $500{ }^{\circ} \mathrm{C}$. Temperatures were recorded by three different thermocouples, one located in contact with the internal wall of the pipe the two others located in the jet at $5 \mathrm{~mm}$ above the middle of the sample surface. The measurement period (240 s) was three times longer than decontamination treatments in order to analyse the functioning of the apparatus. Cooling rate of the internal part of the pipe remained moderate, decreasing by about $10^{\circ} \mathrm{C}$ every $35 \mathrm{~s}$ for an initial 


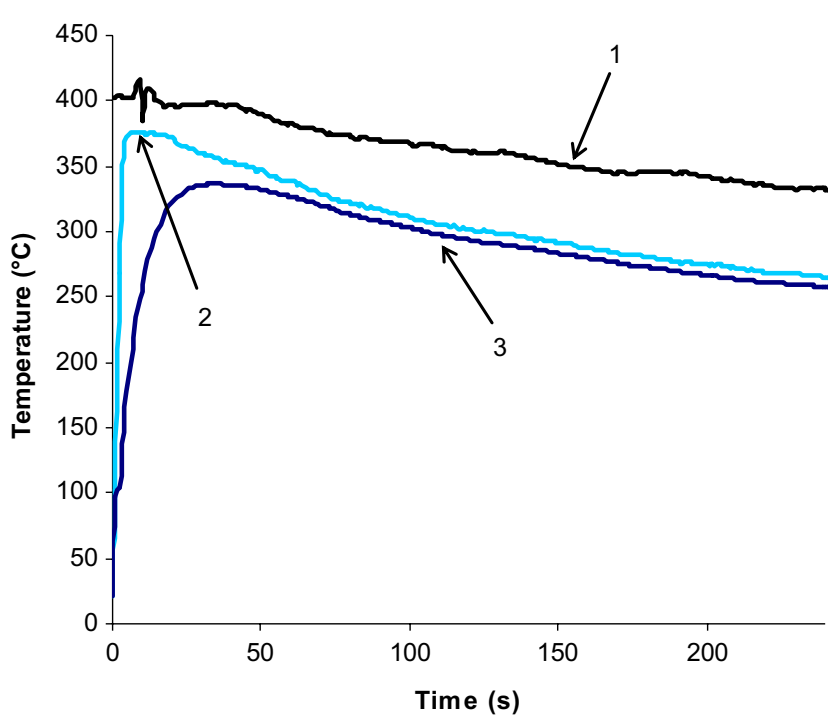

Fig. 2. Analysis of pipe functioning during a jet exhaust of $240 \mathrm{~s}$. Initial temperature of the superheated steam jet is $400{ }^{\circ} \mathrm{C}$. Temperatures are recorded by three thermocouples. The first thermocouple (1) is $0.6 \mathrm{~mm}$ thick and placed in contact with the internal wall of the heating pipe. The two others are located in the jet at $5 \mathrm{~mm}$ (curves 2 and 3 ) above the centre of the sample surface. Thickness of these two thermocouples is $0.6 \mathrm{~mm}(2)$ and $2.3 \mathrm{~mm}(3)$, respectively.

temperature of $400{ }^{\circ} \mathrm{C}$. The temperatures recorded by the thermocouples bound to the sliding system and located just above the centre of the sample increased from the temperature of the ambient air to a maximum value, and then decreased following the cooling of the tube. The time needed to reach the maximum temperature as well as the value of this maximum itself both depended on the thermal inertia of the sensor. In the example given in Fig. 2, it took $17 \mathrm{~s}$ to reach a maximum of $376^{\circ} \mathrm{C}$ for the $0.6 \mathrm{~mm}$-thick thermocouple whereas it took $37 \mathrm{~s}$ to reach $336^{\circ} \mathrm{C}$ for the $2.3 \mathrm{~mm}$-thick thermocouple. During a $30 \mathrm{~s}$ or $60 \mathrm{~s}$, treatment, jet temperature varied continuously. The temperature of the treatment was considered to be the average of the temperatures recorded by the $0.6 \mathrm{~mm}$ thermocouple after it had reached its maximum value. In the example given in Fig. 2, the recorded temperature decreased from a maximum of $376{ }^{\circ} \mathrm{C}$ to $359^{\circ} \mathrm{C}$ and then to $339^{\circ} \mathrm{C}$ after $30 \mathrm{~s}$ and $60 \mathrm{~s}$ of treatment, giving treatment temperatures of $367.5^{\circ} \mathrm{C}$ and $357.5^{\circ} \mathrm{C}$, respectively.

The temperature of the jet which impinged the sample decreased from the centre of the jet to its side where steam mixed with air. This variation was determined at the location of the sample using the circular target previously used for velocity measurements. Jet temperature was measured by a thermocouple located $3 \mathrm{~mm}$ above the target and at the locations given by eight radiuses and four concentric circles (Fig. 1b). The temperature value at each location was obtained by averaging the measurements obtained during 4 min of recordings. Table 2 gives results obtained for an average jet temperature of $127^{\circ} \mathrm{C}$. The temperature clearly decreased from the circle " $a$ " at the centre of the jet to circle " $d$ " which was located at the edge of the sam-
Table 2

Jet temperature $\left({ }^{\circ} \mathrm{C}\right)$ measured by a thermocouple located $3 \mathrm{~mm}$ above the sample covered by the target and at the locations given by eight radiuses and four concentric circles (Fig. 1b)

\begin{tabular}{llllll}
\hline Radius/Circle & $a$ & $b$ & $c$ & $d$ & Average a-d \\
\hline 1 & 134 & 126 & 125 & 128 & 128 \\
2 & 133 & 131 & 135 & 122 & 130 \\
3 & 135 & 133 & 130 & 117 & 129 \\
4 & 135 & 129 & 127 & 123 & 128 \\
5 & 133 & 133 & 122 & 115 & 126 \\
6 & 133 & 128 & 129 & 119 & 127 \\
7 & 131 & 127 & 118 & 122 & 124 \\
8 & 131 & 133 & 123 & 122 & 127 \\
Average 1-7 & 133 & 130 & 126 & 121 & \\
STD 1-7 & 1.7 & 2.8 & 5.5 & 4.0 & \\
\hline
\end{tabular}

The temperature values at each location were obtained by averaging the measurements taken during 4 min of records.

ple. The jet was also warmer on the radiuses " $2,3,4$ ", which were located on the longer side of the pipe bend, than on radiuses " $6,7,8$ " that were located on the shorter side of the bend. Temperature differences remained limited on the different points of circles " $a$ " and " $b$ " located at the centre of the sample where the decontamination treatment was quantified. Thermocouple measurements in jets had to be averaged over long periods and could not provide a clear idea of the space variation of temperature. We therefore used an IR camera in addition to thermocouple measurements in order to detail the heterogeneity of surface temperature on samples subjected to the jet of superheated steam.

Infra-Red systems are able to measure rapidly changing surface temperatures but they require careful calibration. This is a key point which is always difficult to ensure on biological products whose exact emissivities are unknown and whose thermal properties vary during treatments. This problem was further complicated in the present study by the fact that IR measurements had to be performed through a non-transparent medium, i.e. the jet of superheated steam. The jet of superheated steam is not transparent because water vapour can be absorb infrared radiations and that absorbing droplets can form during steam cooling especially at the edge of the jet.

Two methods were developed to determine the effect of the previously mentioned phenomena on the measurements. The first method concerned product emissivity while the second method addressed the effect of the steam nontransparency on IR measurement. The results proved that variation of product emissivity slightly affected the response of the IR sensor compared to the non-transparency of the superheated steam medium. Thus only the second method of calibration is described here. In this method, IR temperature measured through the jet was compared either to the temperature of boiling water or to the temperature of the impinging jet when a treatment was continued for more than $10 \mathrm{~min}$.

During the second period of the heat treatment, condensates evaporated and surface temperature remained 
constant and equal to $T_{\mathrm{eb}}$ until condensates disappeared. Since the experiments were performed at an altitude of $780 \mathrm{~m}$ a.s.1., atmospheric pressure varied between $682 \mathrm{~mm}$ and $701 \mathrm{~mm}$ of $\mathrm{Hg}$ and water boiling temperature $T_{\text {eb }}$, ranged between $97.0^{\circ} \mathrm{C}$ and $97.8^{\circ} \mathrm{C}$. These values matched those recorded by the $2.3 \mathrm{~mm}$-thick thermocouple when it was covered by an evaporating droplet. Table 3 gives the temperatures recorded by the IR pyrometer at the surface of the different samples during the evaporation of condensates. Temperatures measured by the IR pyrometer on the thick, porous Teflon ${ }^{\circledR}$ sample and on the poultry meat were 2.5-3.0 ${ }^{\circ} \mathrm{C}$ lower than $T_{\mathrm{eb}}$. Differences were greater on the Teflon ${ }^{\circledR}$ slides, which were smoother than the thick Teflon ${ }^{\circledR}$ sample, and on the poultry skin. It was very important to check the difference between surface temperature and $T_{\text {eb }}$. Temperature recordings in some experiments were $5-6^{\circ} \mathrm{C}$ lower than those given in Table 3 for a pipe temperature of $150-170{ }^{\circ} \mathrm{C}$. This was due to impingement of cool condensates at the sample surface resulting from insufficient purging of the circuit located upstream of the pipe. These experiments have been eliminated from the present analysis.

When a non-evaporating product is subjected to a hot jet of gas, its surface temperature shall reach the temperature of the gas after a certain period which is shorter with thinner products and products with higher thermal conductivity. Temperatures recorded by the IR pyrometer never reached the jet temperature, even when the treatment was continued for more than $10 \mathrm{~min}$ on the $1 \mathrm{~mm}$-thick Teflon ${ }^{\circledR}$ sample (Fig. 3), and regardless of the initial pipe temperature, i.e. $200^{\circ} \mathrm{C}, 250{ }^{\circ} \mathrm{C}, 400^{\circ} \mathrm{C}$, or $500^{\circ} \mathrm{C}$. IR-recorded temperatures peaked after about 1-2 min of treatment depending on the initial temperature of the pipe, then decreased following pipe cooling (Fig. 3). Approximate analytical calculations proved that after $250 \mathrm{~s}$ of treatment, the temperature at the surface of the Teflon ${ }^{\circledR}$ slide should match the temperature of the jet. The required matching between jet and surface temperatures after $250 \mathrm{~s}$ of treatment was carefully checked afterwards using numerical simulations. IR temperatures recorded on Teflon ${ }^{\circledR}$ slides after $250 \mathrm{~s}$ of treatment were subtracted from the jet temperature measured by the calibrated $0.6 \mathrm{~mm}$ thermocouple. This difference was used to calibrate the IR pyrometer in the range $185-340{ }^{\circ} \mathrm{C}$. Because of the non-transparency

Table 3

Temperature $\left({ }^{\circ} \mathrm{C}\right)$ recorded by the IR pyrometer at the surface of the different samples during condensate evaporation

\begin{tabular}{llc}
\hline Sample & IR temperature & Temperature correction \\
\hline Teflon $20 \mathrm{~mm}$ & 95.0 & 2.5 \\
Teflon $1 \mathrm{~mm}$ & 93.7 & 3.8 \\
Muscle only & 94.6 & 2,9 \\
Muscle + skin & 93.3 & 4.2 \\
Skin only & 92.8 & 4.7
\end{tabular}

Correction was calculated from the difference between the theoretical values given by the temperature of boiling water at a pressure of $698 \mathrm{~mm}$ $\mathrm{Hg}\left(97.5^{\circ} \mathrm{C}\right)$ and IR measurements.

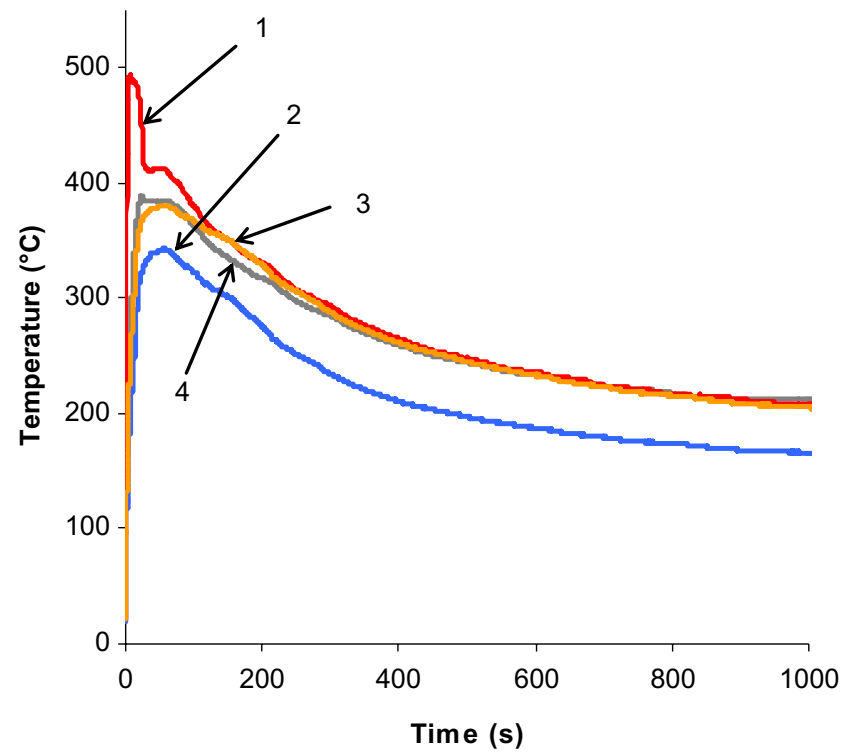

Fig. 3. Comparison of the jet temperature measured by the $0.6 \mathrm{~mm}$-thick thermocouple with the temperature recorded by the IR pyrometer at the surface of the $1 \mathrm{~mm}$-thick Teflon ${ }^{\circledR}$ sample subjected to the jet for more than $10 \mathrm{~min}$ : (1) jet temperature, (2) raw IR response, (3) calibrated IR response, and (4) predictions of the transfer model.

of the superheated steam jet, the IR sensor underestimated the surface temperature of the $1 \mathrm{~mm}$ Teflon ${ }^{\circledR}$ sample by more than $50{ }^{\circ} \mathrm{C}$ for a surface temperature of $250^{\circ} \mathrm{C}$. The following equation was used to correct the response of the IR sensor $T_{\mathrm{ir}}$, in the higher temperature range:

$T_{\text {cor }}=-1.9810^{-3} T_{\text {ir }}^{2}+1.99 T_{\text {ir }}-71.94$ for $T_{\text {ir }} \geqslant 150{ }^{\circ} \mathrm{C}$

For temperatures below $98^{\circ} \mathrm{C}$, the IR response was corrected by linear regression in such a way that the corrected value equalled $T_{\mathrm{eb}}$ during condensate evaporation:

$T_{\text {cor }}=1.04 T_{\text {ir }}$ for $T_{\text {ir }} \leqslant 95^{\circ} \mathrm{C}$

A linear regression was established to connect the two previous relations:

$T_{\text {cor }}=1.55 T_{\text {ir }}-45.49$ for $95^{\circ} \mathrm{C}<T_{\text {ir }}<150{ }^{\circ} \mathrm{C}$

Perturbation due to the non-transparency of the jet had the same effect on the IR pyrometer and the IR camera. The method of calibration could not be applied on poultry samples since evaporation and cooking-related phenomena would most probably have led to differences between surface temperatures and jet temperatures, even after long treatment periods. As the effect of product emissivity was much lower than the jet non-transparency-related perturbations, it was accepted that relations (7)-(9) were also valid for poultry samples.

Uniformity of treatment was analysed using an IR camera (Aviowin 2000, HGH, France) which was mostly sensitive to IR radiations between $3 \mu \mathrm{m}$ and $5 \mu \mathrm{m}$ and whose accuracy according to the manufacturer was $2 \%$ of the nominal value in the range $0-300{ }^{\circ} \mathrm{C}$. The thermocouples 
were removed during IR imaging. Images were acquired on the $2.0 \mathrm{~cm}$-thick Teflon ${ }^{\circledR}$ sample subjected to a jet temperature of $200{ }^{\circ} \mathrm{C}$ at different treatment durations between $5 \mathrm{~s}$ and $1500 \mathrm{~s}$. Files were imported in ASCII format to Matlab 7.0 software for processing using the functions of the Matlab image processing toolbox.The matrix of temperature data issued from the ASII file was statistically analysed. Despite a distance of more than 20 diameters between the pipe outlet and the pipe bend, the jet flow nevertheless remained influenced by this bend. Jet velocity and temperature remained greater on the side corresponding to the outside (longer) part of the bend than on the side following on from its inner (shorter) part. This was reinforced by a higher concentration of water droplets on the inner side of the bend. At the beginning of thermal treatment, the higher velocity and the lower droplet content on the outside part of the jet led to a crescent-shaped area of higher surface temperature (Fig. 4a, 1). The difference of velocity in the impinging jet also led to a flow at the sample surface being directed towards the inner side of the pipe. This flow was blocked by the thermocouples stand (Fig. 4a, 2) and dragged along the condensation droplets formed at the surface of the sample which concentrated in two kidney shape areas located on the two other sides of the sample (Fig. 4a, 3 ). The higher droplet content in the inner part of the impinging jet as well as droplet movement at the surface of the sample were tracked visually during the experiments. When the treatment was continued over several minutes, there was a decrease in the number of droplets in the jet and at the sample surface. Fewer differences were observed between the two different sides of the pipe, and the hottest area moved towards the centre of the sample. Table 4 presents the changes in the location of the hottest area on the sample radius and in the difference between the temperatures on the two sides of the sample. Temperature differences increased during the first seconds of treatment to reach $36{ }^{\circ} \mathrm{C}$ after $90 \mathrm{~s}$ of treatment, thereafter decreasing rapidly during the following $10 \mathrm{~min}$ and then at a slower rate until reaching about $10^{\circ} \mathrm{C}$ at the end of the experiment. The hottest area, which at the beginning was found near the edge of the sample in the direction of the outside of the bend, shifted in a relatively regular fashion towards the centre. After $1500 \mathrm{~s}$ of treatment, infrared images just showed a decreased in temperature between the centre of the jet and its side due to steam being mixed with air (Fig. 4b).

Statistical analyses were run on the surface temperatures recorded in the area located at the middle of the sample and outlined by the circle $2 \mathrm{~cm}$ in diameter where the temperature was averaged by the IR pyrometer (Table 5). Local deviation between the temperature recorded by the IR camera and the averages was significant during the 10 first seconds of treatment, thereafter decreasing sharply for the following $40 \mathrm{~s}$. The standard deviation was highest in the $y$ direction, corresponding to the tube bending, than in the $x$ direction (Fig. 4), reaching about $5-6^{\circ} \mathrm{C}$ in the $y$ direction over durations of a $30-60 \mathrm{~s}$, although point-topoint differences of $15-22{ }^{\circ} \mathrm{C}$ were also recorded, giving a maximum deviation of $12 \%$ on the measured temperature (Table 5). It was concluded that surface temperature was sufficiently uniform in the central measurement zone of the pyrometer to be dynamically analysed as an average.

\subsection{Experimental variation of surface temperature}

Fig. 5 presents the surface temperature patterns measured by the calibrated pyrometer on the $20 \mathrm{~mm}$ and $1 \mathrm{~mm}$-thick Teflon ${ }^{\circledR}$ samples for different jet temperatures ranging from $150{ }^{\circ} \mathrm{C}$ to $373{ }^{\circ} \mathrm{C}$. The steam treatment lasted about $30 \mathrm{~s}$ and was stopped by cooling the surface with the cold air jet. The four different periods of the treatment are clearly observable: (1) a first period of $0.7-1$ s of steam condensation while surface temperatures rose from ambient temperature (about $20^{\circ} \mathrm{C}$ ) to water boiling temperature (in our case about $97^{\circ} \mathrm{C}$ ), (2) a second period of condensate
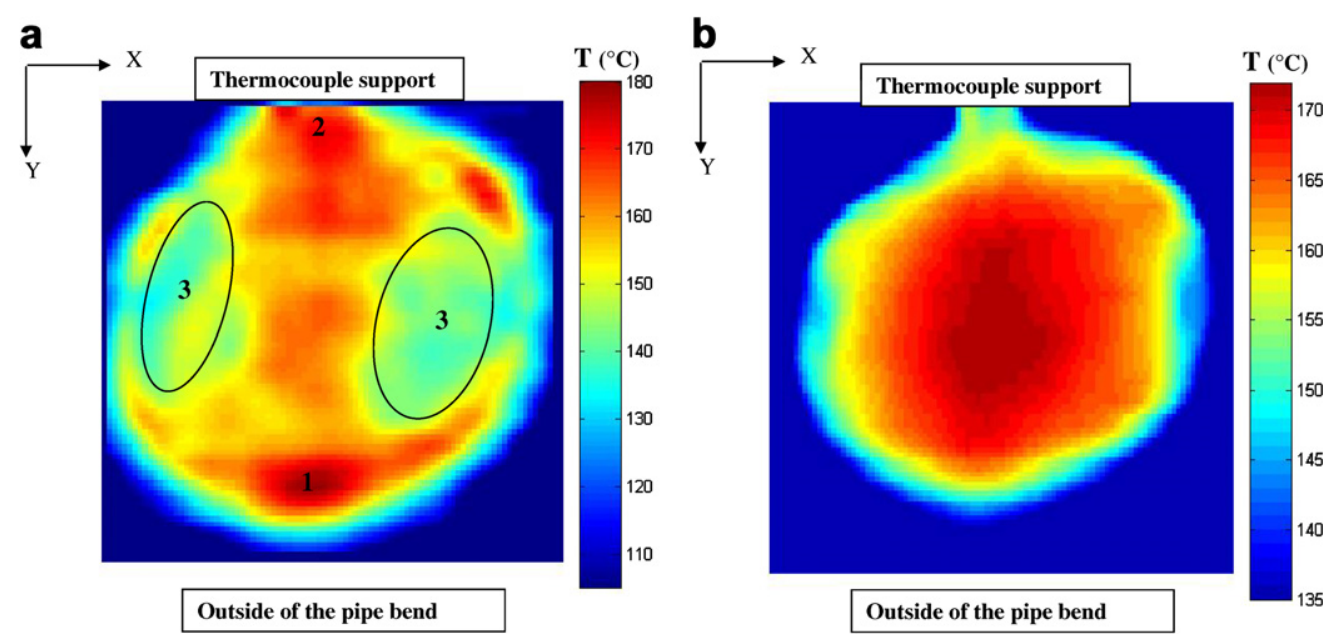

Fig. 4. Images of the temperature at the surface of the $2.0 \mathrm{~cm}$-thick Teflon ${ }^{\circledR}$ sample subjected to a jet at a temperature of $200{ }^{\circ} \mathrm{C}$ : (a) after $5 \mathrm{~s}$ of treatment, (b) after $1500 \mathrm{~s}$ of treatment. Images were acquired by an IR camera (Aviowin 2000, HGH, France) and processed by software using the image processing Toolbox of Matlab 7.0 . 
Table 4

Analysis of the IR images recorded at the surface of the $2 \mathrm{~cm}$-thick Teflon $^{\circledR}$ sample during a $1500 \mathrm{~s}$ treatment

\begin{tabular}{rll}
\hline Time (s) & $\begin{array}{l}\text { Location of the } \\
\text { hottest point }(\mathrm{mm} \\
\text { from the centre) }\end{array}$ & $\begin{array}{l}\text { Difference of temperature } \\
\text { between the hottest } \\
\text { and the coldest area }\left({ }^{\circ} \mathrm{C}\right)\end{array}$ \\
\hline 5 & 23.0 & 8.7 \\
12 & 23.0 & 21.8 \\
20 & 24.0 & 23.8 \\
30 & 21.2 & 31.1 \\
50 & 21.6 & 35.5 \\
90 & 21.5 & 36.0 \\
150 & 21.4 & 32.6 \\
240 & 18.4 & 28.1 \\
420 & 18.6 & 19.3 \\
600 & 18.1 & 15.9 \\
780 & 17.4 & 15.8 \\
960 & 9.9 & 12.5 \\
1200 & 7.6 & 12.8 \\
1500 & 5.2 & 11.2 \\
\hline
\end{tabular}

The hottest area in the images shifts along cylinder radius 5 (Fig. 1b). A distance of $25.0 \mathrm{~mm}$ corresponds to the edge of the sample and $0 \mathrm{~mm}$ to its centre. Temperature differences were calculated between the hottest and coldest areas in the image.

evaporation while surface temperature remained constant, (3) a third period of convection heating of the surface by the steam jet flow (not observed for the $150{ }^{\circ} \mathrm{C}$ steam treatment), and (4) the final period of convection cooling with the cold air jet. Condensate evaporation was quicker for more overheated steam jet. Temperature kinetics were the similar on the two samples when jet temperature was lower than $300^{\circ} \mathrm{C}$. In this case, condensate evaporation governs the heating of the sample and was independent of the thickness and smoothness of the sample. In contrast, when the jet temperature was higher than $300{ }^{\circ} \mathrm{C}$, surface heating was governed by convection, and the maximum surface temperature reached at the end of the treatment was higher on the $1 \mathrm{~mm}$-thick Teflon $^{\circledR}$ sample than on the $20 \mathrm{~mm}$ thick sample.
Fig. 6a and $\mathrm{b}$ present the results obtained on skin and on poultry muscle without skin, respectively. In Fig. 6a, skin thickness ranges from $0.9 \mathrm{~mm}$ to $1.1 \mathrm{~mm}$. The results measured on the muscle with skin (not shown) were similar but more complex than those obtained on skin alone. When the temperature of the superheated steam jet was lower than $200-250{ }^{\circ} \mathrm{C}$, the skin remains in contact with the muscle, but at higher jet temperatures the skin suddenly "puffed out", becoming clearly separated from the muscle, while surface temperature remained the same as when the skin was treated alone. Variations in temperature were much more erratic at the surface of the poultry skin (Fig. 6a) than on Teflon ${ }^{\circledR}$ due to: lipid fusion, surface evaporation, skin cooking, and shrinkage. The four treatment periods observed on Teflon ${ }^{\circledR}$ were nevertheless clearly reproduced on the skin sample, and temperature values were very similar to those measured on the $20 \mathrm{~mm}$-thick Teflon ${ }^{\circledR}$ sample. Logically, surface temperatures should be closer to those obtained on the thin Teflon ${ }^{\circledR}$ slides, but this discrepancy can be explained by: (1) potential differences in thermal conductivity between Teflon ${ }^{\circledR}$ and skin (exact thermal conductivity of the skin remaining unknown) and (2) complex phase changes occurring at the skin surface. It was also observed that a droplet evaporated more rapidly on skin than on Teflon ${ }^{\circledR}$. The authors wondered whether the not perfectly flat shape of the poultry skin led to a gravity-driven droplet flow, which could also explain some of the differences. Experiments were performed by sloping the surface of a Teflon ${ }^{\circledR}$ sample at an angle of $45^{\circ}$, and the results were the same as when the surface was horizontal This is in accordance with the slight effect of gravity on droplet evaporation reported by Grandas et al. (2005) on aluminium surfaces. Thus, differences in droplet evaporation between poultry and Teflon ${ }^{\circledR}$ were probably due to differences in surface wetting and not to differences in surface relief.

Temperature kinetics were very different on poultry muscle compared to on skin or on Teflon ${ }^{\circledR}$ (Fig. 6b). The

Table 5

Statistical analysis of the temperature data $\left({ }^{\circ} \mathrm{C}\right)$ in the $2 \mathrm{~cm}$ diameter spot at the centre of the IR images

\begin{tabular}{|c|c|c|c|c|c|c|c|}
\hline Time (s) & Mean & Stdy & $\operatorname{Std} x$ & $\operatorname{Max}$ & Min & Max-Mean & Min-Mean \\
\hline 5 & 154.5 & 5.9 & 1.4 & 164.9 & 139.1 & 10.4 & 15.4 \\
\hline 12 & 180.2 & 9.4 & 0.7 & 192.4 & 157.3 & 12.2 & 22.9 \\
\hline 20 & 205.6 & 5.7 & 1.0 & 214.5 & 190.3 & 8.9 & 15.3 \\
\hline 30 & 218.4 & 4.5 & 0.5 & 224.0 & 206.1 & 5.6 & 12.3 \\
\hline 50 & 234.2 & 3.4 & 1.1 & 240.5 & 224.1 & 6.3 & 10.0 \\
\hline 90 & 242.9 & 3.6 & 0.6 & 250.8 & 231.5 & 7.9 & 11.4 \\
\hline 150 & 239.9 & 2.1 & 1.1 & 246.8 & 229.5 & 6.8 & 10.4 \\
\hline 240 & 226.9 & 1.4 & 2.2 & 235.1 & 217.8 & 8.2 & 9.1 \\
\hline 420 & 208.5 & 1.0 & 1.7 & 213.5 & 201.7 & 5.0 & 6.8 \\
\hline 600 & 195.5 & 1.6 & 1.8 & 200.2 & 188.8 & 4.7 & 6.7 \\
\hline 780 & 185.1 & 1.4 & 1.0 & 188.0 & 178.2 & 2.9 & 6.8 \\
\hline 960 & 179.1 & 1.4 & 0.7 & 182.0 & 172.7 & 2.9 & 6.4 \\
\hline 1200 & 173.3 & 1.4 & 0.7 & 176.0 & 166.9 & 2.7 & 6.4 \\
\hline 1500 & 169.3 & 1.5 & 0.9 & 172.0 & 163.1 & 2.7 & 6.2 \\
\hline
\end{tabular}

This zone corresponds to the measurement spot of the IR pyrometer. Average, maximum and minimum temperature values were calculated for inside the spot and were then used to determine the extreme differences existing in the total image area. Std $x$ and Std $y$ are the standard deviation of the measurement in the spot in the $x$ and $y$ directions given in Fig. 4, respectively. 


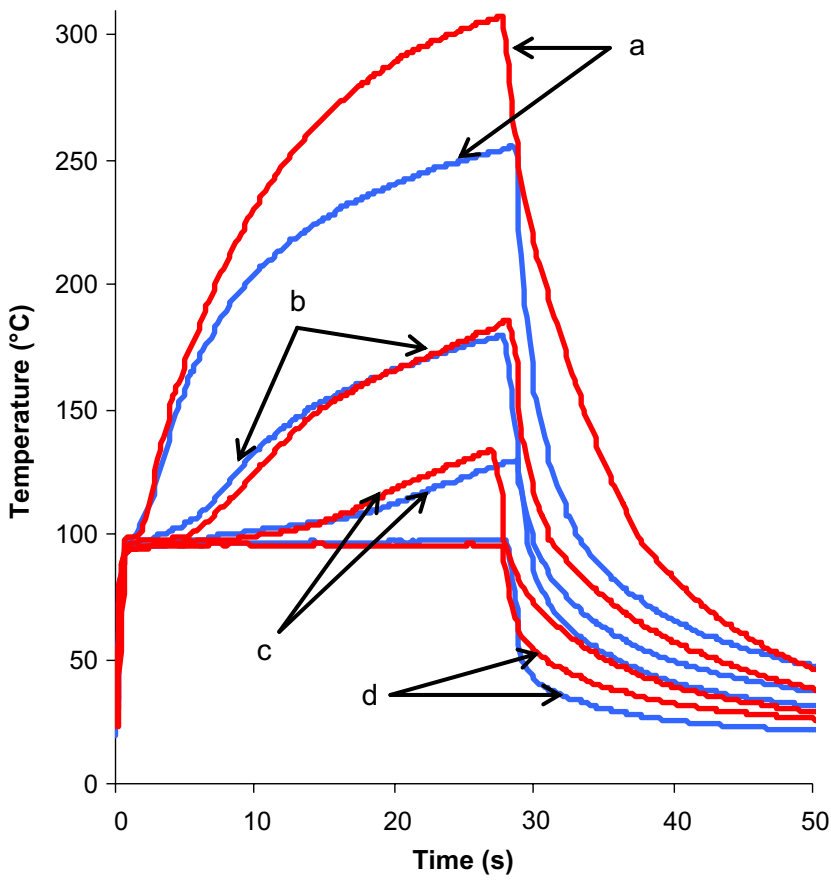

Fig. 5. Changes in surface temperature measured by the calibrated IR pyrometer on the $20 \mathrm{~mm}$-thick (blue curves) and on the $1 \mathrm{~mm}$-thick (red curves) Teflon ${ }^{\circledR}$ samples for different jet temperatures: $151{ }^{\circ} \mathrm{C}(\mathrm{d}), 219^{\circ} \mathrm{C}$ (c), $260^{\circ} \mathrm{C}$ (b), and $373{ }^{\circ} \mathrm{C}$ (a). The steam treatment lasts $30 \mathrm{~s}$ and is stopped by cooling of the surface. The four different periods of the treatment are clearly observable: (1) steam condensation, (2) condensate evaporation, (3) convection heating of the surface by steam jet flow (not observed for the $151{ }^{\circ} \mathrm{C}$ steam treatment), and (4) a final period of convection cooling by the cold air jet. (For interpretation of the references to colour in this figure legend, the reader is referred to the conversion of this article.)

progressive shortening of the period of constant temperature was never observed on muscle. At a jet temperature of below $200^{\circ} \mathrm{C}$, surface temperature always remained very close to $T_{\mathrm{eb}}$, whereas at jet temperatures greater than $250{ }^{\circ} \mathrm{C}$ there was no period of constant temperature. This is probably explained by the fact that condensates are no more able to evaporate freely from the surface. One can assume that condensates become somehow bound to the cooking muscle or to a juice of lipids and peptides coming from this muscle (water activity becoming much lower than one). In this scenario, the heating treatment only split into in two periods: a first period of steam condensation, and a second period of water evaporation, with water coming mainly from the product itself and not from condensates.

\subsection{Comparison of measurements with model predictions}

\subsubsection{Choice of model parameters}

Given that the thermal properties of Teflon ${ }^{\circledR}$ are well known (at least up to a temperature of $60^{\circ} \mathrm{C}$ ), the following inlet parameters were introduced into the model to define the boundary conditions on the upside surface of the sample: $h_{\mathrm{eb}}, h_{\text {conv }}$, and $h_{\text {cool }}$. Two other parameters, i.e. $T_{\text {bottom }}$ and $h_{\text {bottom, }}$ were involved in the definition of the exchange by conduction on the downside of the sample.
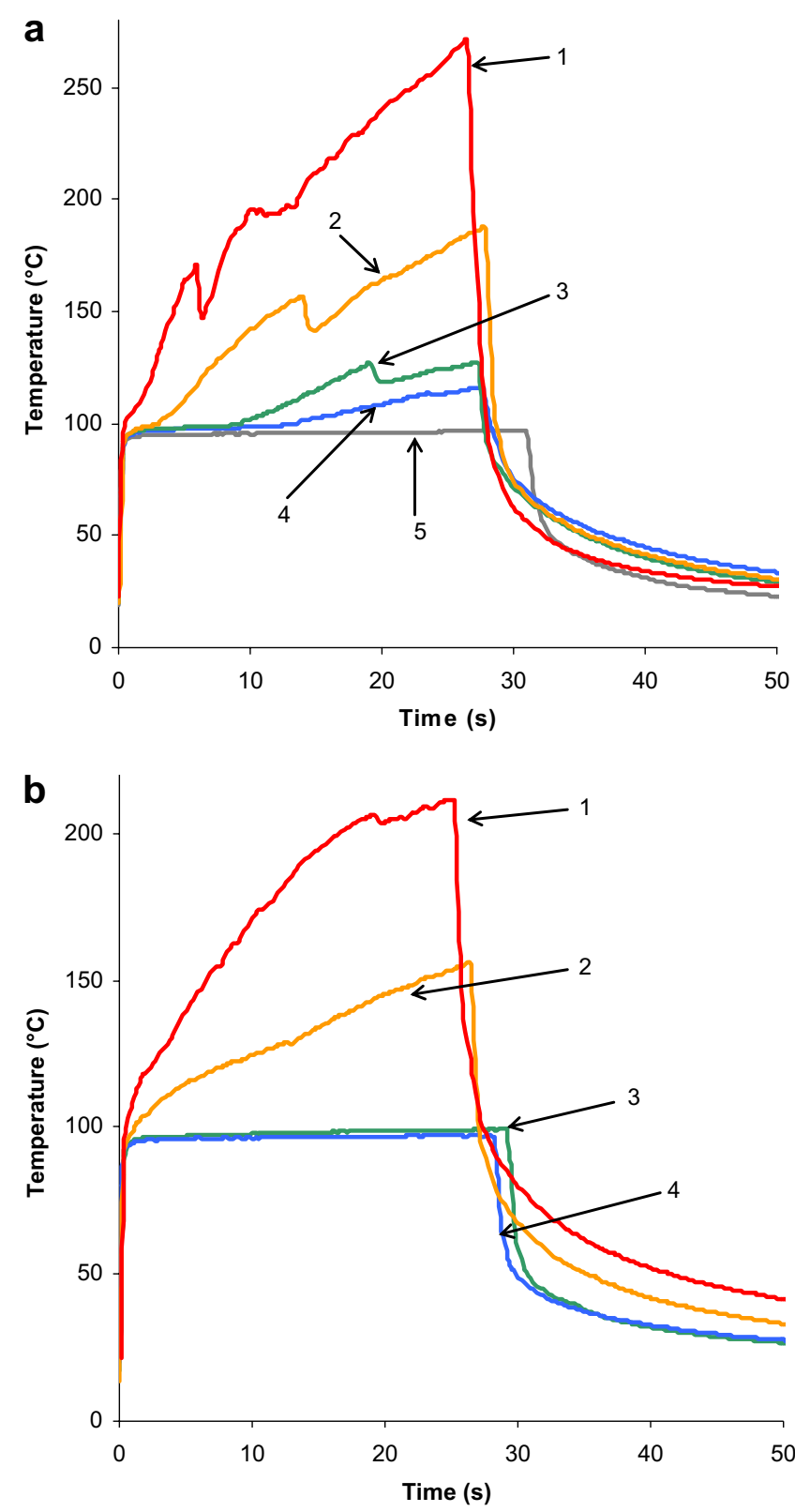

Fig. 6. Temperatures measured at the surface of: (a) poultry skin and (b) poultry muscle. Skin thickness ranges from $0.9 \mathrm{~mm}$ to $1.1 \mathrm{~mm}$. Surface temperature variations were much more erratic on skin than on Teflon ${ }^{\circledR}$ due to cooking-related phenomena. The four periods of treatment observed on Teflon ${ }^{\circledR}$ remain clearly visible on skin, whereas the kinetics were different on poultry muscle. Changes in surface temperatures measured by the calibrated IR pyrometer at $434{ }^{\circ} \mathrm{C}(1), 340{ }^{\circ} \mathrm{C}$ (2), $249^{\circ} \mathrm{C}(3), 218^{\circ} \mathrm{C} \mathrm{(4),} \mathrm{and} 151^{\circ} \mathrm{C}(5)$ for (a) and $454{ }^{\circ} \mathrm{C}(1), 352^{\circ} \mathrm{C}(2)$, $200{ }^{\circ} \mathrm{C}(3)$, and $151{ }^{\circ} \mathrm{C}$ (4) for (b).

Transfer coefficient values used on the upside surface of the Teflon ${ }^{\circledR}$ sample can be determined via a stepwise approach, fitting $h_{\text {cond }}^{0}$ on the slope of the initial temperature rise, then $h_{\mathrm{eb}}$ on the duration of the evaporating period, $h_{\mathrm{conv}}$ on the final rise in temperature, and $h_{\text {cool }}$ on the cooling period.

The initial transfer coefficient value which describes the condensation of steam on the sample surface, had to be less than $1000 \mathrm{~W} \mathrm{~m}^{-2} \mathrm{~K}^{-1}$, since transfers do not occur in pure 
steam but in a mixture of steam and air. It was found during our simulation that the value of $774 \mathrm{~W} \mathrm{~m}^{-2} \mathrm{~K}^{-1}$ for $h_{\text {cond }}^{0}$ was sufficient to describe the first period of treatment. Sensitivity analysis proved that the exchange by conduction between the downside of the $2 \mathrm{~cm}$-thick Teflon ${ }^{\circledR}$ sample and its support did not affect the prediction of temperature on sample's upside surface, while downside conduction could not be neglected in the case of the 1 mm-thick Teflon ${ }^{\circledR}$ sample. Because flux at one boundary surface directly affected the temperature on the other surface even though the treatment time was short and the Teflon ${ }^{\circledR}$ was an isolating material. Thus, upside boundary conditions were first determined on the $2 \mathrm{~cm}$-thick Teflon ${ }^{\circledR}$ sample and then applied to the $1 \mathrm{~mm}$-thick Teflon ${ }^{\circledR}$ sample to determine $T_{\text {bottom }}$ and $h_{\text {bottom. It was found that the best }}$ set of parameters for the upside boundary conditions were: $h_{\mathrm{eb}}=20 \mathrm{~W} \mathrm{~m}^{-2} \mathrm{~K}^{-1}, h_{\text {conv }}=200 \mathrm{~W} \mathrm{~m}^{-2} \mathrm{~K}^{-1}$, and $h_{\text {cool }}=$ $240 \mathrm{~W} \mathrm{~m}^{-2} \mathrm{~K}^{-1}$ (Fig. 7). This $h_{\text {cool }}$ value is in accordance with what can be calculated from (5) using the velocity measurements at the cold jet outlet $\left(220-260 \mathrm{~W} \mathrm{~m}^{-2} \mathrm{~K}^{-1}\right)$. Steam velocity in the superheated steam jet was assessed using relation (6) and the properties of superheated steam given by Devahastin and Mujumbar (2000). The initial pressure of the steam before release ranged between 5.5 bars and 7.0 bars. The decrease in pressure after release could not be determined precisely due to the inaccuracy of the steam pressure gauge. Calculations from (6) lead to a steam velocity of about $20 \mathrm{~m} \mathrm{~s}^{-1}$. However, this value is probably overestimated, since the calculations do not take

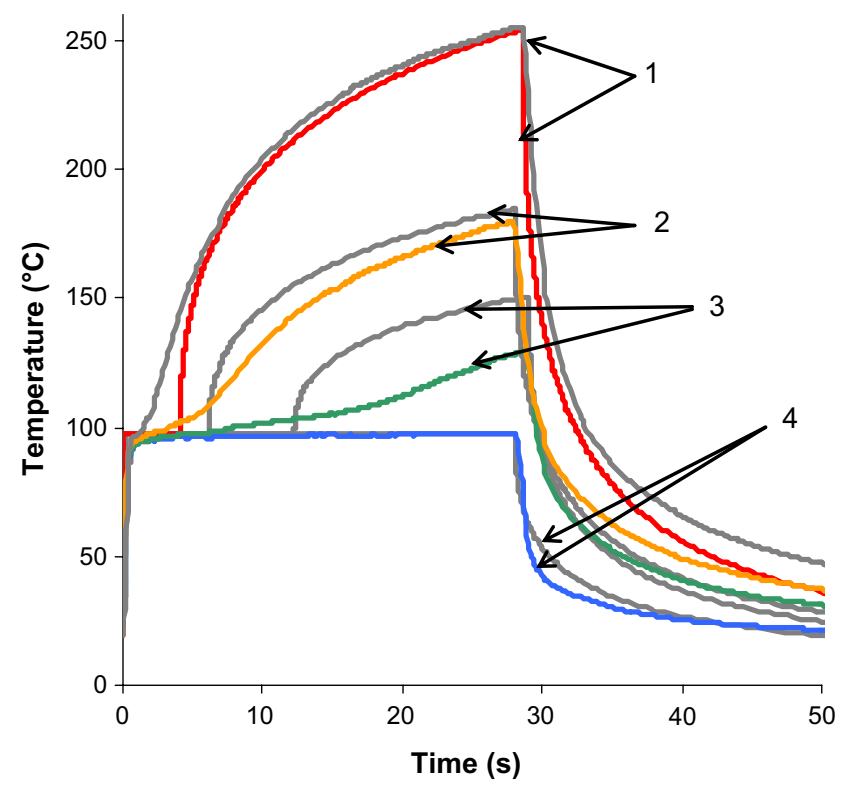

Fig. 7. Comparison between the results measured on the $2 \mathrm{~cm}$-thick Teflon ${ }^{\circledR}$ sample (colour curves) and the model predictions (grey curves) $\left(\lambda=0.23 \mathrm{~W} \mathrm{~m}^{-1} \mathrm{~K}^{-1}, D_{\mathrm{T}}=1.04 \times 10^{-7} \mathrm{~m}^{2} \mathrm{~s}^{-1}, h_{\text {cond }}^{0}=774 \mathrm{~W} \mathrm{~m} \mathrm{~m}^{-2} \mathrm{~K}^{-1}\right.$, $h_{\mathrm{eb}}=20 \mathrm{~W} \mathrm{~m}^{-2} \mathrm{~K}^{-1}, \quad h_{\text {conv }}=200 \mathrm{~W} \mathrm{~m}^{-2} \mathrm{~K}^{-1}$, and $h_{\text {cool }}=240 \mathrm{~W} \mathrm{~m}^{-2}$ $\mathrm{K}^{-1}$ ). Predictions are in accordance with measurements for $T_{\text {steam }}>$ $260^{\circ} \mathrm{C}$, while the model overestimates measurements at lower jet temperatures. Steam jet temperature is: $368^{\circ} \mathrm{C}(1), 262.5^{\circ} \mathrm{C}(2), 214^{\circ} \mathrm{C}$ (3), and $151{ }^{\circ} \mathrm{C}$ (4). (For interpretation of the references to colour in this figure legend, the reader is referred to the conversion of this article.) into account temperature variations or friction and condensation phenomena. Relation (5) cannot be used for the superheated steam jet since $r / D$ was $1.5((5)$ is valid for $r / D>2.5)$ and thus it is difficult to further discuss the value of $h_{\text {conv }}$. However, the estimated Reynolds number for steam appeared comparable to that of cold air, and it is reasonable to suppose that $h_{\text {conv }}$ and $h_{\text {cool }}$ were of the same magnitude.

\subsubsection{Temperature predictions on the $20 \mathrm{~mm}$-thick Teflon sample}

Results calculated with these parameter values for $T_{\text {steam }}$ higher than $260{ }^{\circ} \mathrm{C}$ are in accordance with the measured values, whereas the model overestimates the temperatures measured for $T_{\text {steam }}$ lower than $260{ }^{\circ} \mathrm{C}$ (Fig. 7) by as much as $20^{\circ} \mathrm{C}$. Moreover, the shape of the curves predicted during the convection heating period was not consistent with the experimental observations. For $T_{\text {steam }} \leqslant 214^{\circ} \mathrm{C}$, the increase in $T_{\mathrm{s}}$ from $T_{\mathrm{eb}}$ was almost linear while for $T_{\text {steam }} \geqslant 260{ }^{\circ} \mathrm{C}$ the increase in $T_{\mathrm{s}}$, which at first is moderate, then accelerates abruptly, leading to a change in the curvature of the experimental curves. Predictions always led to the same immediate rise of surface temperature from $T_{\mathrm{eb}}$ whatever the jet conditions. This discrepancy is due to the model's assumption that condensates evaporate in the same way as a film of water. The sudden rise in surface temperature is explained by the film disappearing. Experimentally, it can be observed that steam condenses in droplets of different sizes which afterwards evaporate. The end of evaporation is not sudden, since dry hot areas coexist with remaining droplets whose temperature is still $T_{\mathrm{eb}}$. The IR pyrometer gives an average of the temperatures of the different areas included in its area of measurement. This reality can be mimicked in the model by varying $h_{\mathrm{eb}}$ around a mean value and then averaging the calculated results. This approach was developed on the thick Teflon ${ }^{\circledR}$ sample. Fifteen sets of surface temperature kinetics were generated and then averaged across the following of $h_{\mathrm{eb}}$ intervals: $10.5 \pm 7.5 \mathrm{~W} \mathrm{~m}^{-2} \mathrm{~K}^{-1}, \quad 15.5 \pm 6.5 \mathrm{~W} \mathrm{~m}^{-2} \mathrm{~K}^{-1}$, and $23.5 \pm 6.5 \mathrm{~W} \mathrm{~m}^{-2} \mathrm{~K}^{-1}$ for the three jet temperatures $214^{\circ} \mathrm{C}, 262.5^{\circ} \mathrm{C}$, and $368^{\circ} \mathrm{C}$, respectively. The resulting calculations reproduced the measurements very well (Fig. 8). This is an important result, as it proves that droplet evaporation and wetting effects are the main factors affecting temperature kinetics when $T_{\text {steam }} \leqslant 260^{\circ} \mathrm{C}$. For higher value of $T_{\text {steam }}$, kinetics of temperature are affected more by heating of the dried surface than by wettability. However, the previous modelling approach nevertheless remains unsatisfactory in some aspects, even if it does reproduce experimental results. The $h_{\mathrm{eb}}$ value and its range of variation have no fundamental basis, and had to be fitted to experimental data.

\subsubsection{Temperature predictions on the $1 \mathrm{~mm}$-thick Teflon sample}

Calculations were repeated on the $1 \mathrm{~mm}$-thick Teflon ${ }^{\circledR}$ sample using, on its upside surface, the same transfer 


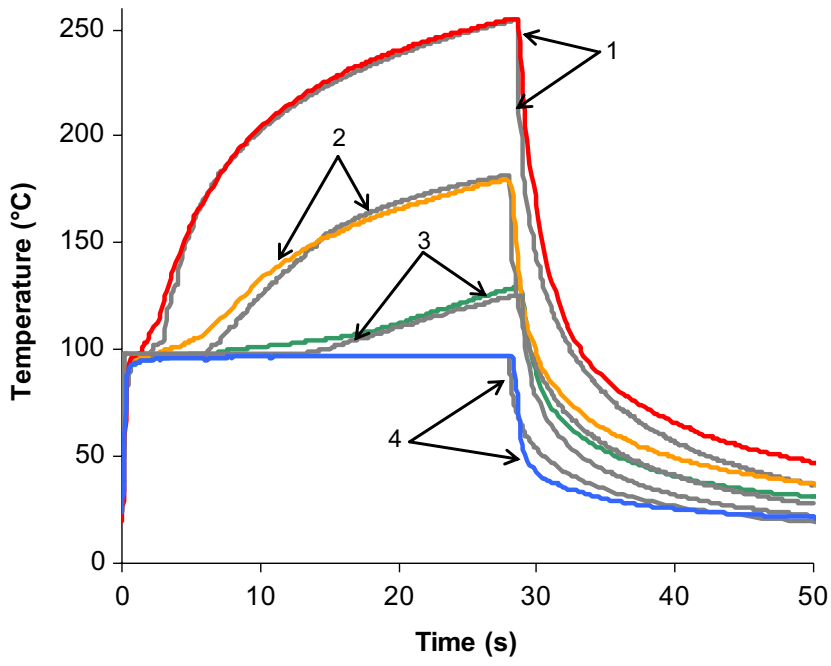

Fig. 8. Comparison between the results measured on the $2 \mathrm{~cm}$-thick Teflon $^{\circledR}$ sample (colour curves) and the model predictions (grey curves). Although model parameters are the same as in Fig. 7, droplet evaporation is mimicked by varying $h_{\mathrm{eb}}$ around its mean value and then averaging the calculated results. In this scenario, 15 sets of kinetics were generated and then averaged in the $h_{\mathrm{eb}}$ interval: $10.5 \pm 7.5 \mathrm{~W} \mathrm{~m}^{-2} \mathrm{~K}^{-1}, 15.5 \pm 6.5$ $\mathrm{W} \mathrm{m} \mathrm{m}^{-2} \mathrm{~K}^{-1}$, and $23.5 \pm 6.5 \mathrm{~W} \mathrm{~m}^{-2} \mathrm{~K}^{-1}$ for the three jet temperatures $214^{\circ} \mathrm{C}, 262.5^{\circ} \mathrm{C}$, and $368^{\circ} \mathrm{C}$, respectively. Experimental steam jet temperature is: $368^{\circ} \mathrm{C}(1), 262.5^{\circ} \mathrm{C}(2), 214^{\circ} \mathrm{C}(3)$, and $151^{\circ} \mathrm{C}$ (4). (For interpretation of the references to colour in this figure legend, the reader is referred to the conversion of this article.)

coefficient as for the $2 \mathrm{~cm}$-thick sample $\left(h_{\mathrm{eb}}=20 \mathrm{~W}\right.$ $\mathrm{m}^{-2} \mathrm{~K}^{-1}, \quad h_{\text {conv }}=200 \mathrm{~W} \mathrm{~m}^{-2} \mathrm{~K}^{-1}, \quad$ and $h_{\text {cool }}=240$ $\mathrm{W} \mathrm{m}{ }^{-2} \mathrm{~K}^{-1}$ ). The best representation of all the experimental results measured under different jet temperatures was obtained by considering that $h_{\text {bottom }}=30 \mathrm{~W} \mathrm{~m}^{-2} \mathrm{~K}^{-1}$ and by equating $T_{\text {bottom }}$ to the average temperature calculated at the bottom of the sample. Calculated results were still different to IR measurements due to the sudden rise in surface temperature after the predicted disappearance of the condensate film. The approach based on the variation of $h_{\mathrm{eb}}$ that was previously developed for the thick Teflon ${ }^{\circledR}$ sample was reproduced on the Teflon ${ }^{\circledR}$ slide, and was also found to be successful. Surface temperature was calculated on the Teflon ${ }^{\circledR}$ slide under the conditions of Fig. 3. During this long treatment of $1000 \mathrm{~s}$, droplet condensation and evaporation are very brief compared to the period of heating by convection. Exact values for and $h_{\mathrm{eb}}$ are much less important than for short treatments. Surface temperature predicted using the same parameters as previously was in good agreement with the calibrated response of the pyrometer (Fig. 3), and slight differences were explained by the constancy of the $h_{\text {bottom }}$ and of $T_{\text {bottom }}$ values introduced for the simulation of this long treatment. Calculations proved that the temperature at the surface of the Teflon ${ }^{\circledR}$ slide actually reaches the jet temperature after a period of $250 \mathrm{~s}$.

\subsubsection{Temperature predictions on the poultry samples}

Heat transfer at the surface of unwrapped food products subjected to superheated steam jets is associated with a mass transfer due to evaporation of liquids (including water, lipids, etc.). Heating is also associated with cooking-related phenomena, including lipid fusion and protein coagulation. The modelling of these phenomena is beyond the scope of this paper, but they can be taken into account in our model by using effective transfer coefficient values for $h_{\text {conv }}$ and $h_{\text {cool }}$. Since surface hydrophobicity is likely to be different between poultry and Teflon ${ }^{\circledR}$, then droplet condensation and evaporation, and thus and $h_{\mathrm{eb}}$ values, will probably be different in the two cases. However, as nothing is known about these values, it was decided to give the same value as for Teflon $\AA$, and to vary $h_{\mathrm{eb}}$ alone, in order to facilitate the comparison between Teflon ${ }^{\circledR}$ and poultry.

Thermal conductivity and diffusivity of raw poultry meat are well known, ranging from $20^{\circ} \mathrm{C}$ to $60^{\circ} \mathrm{C}$ : $\lambda=0.50 \mathrm{~W} \mathrm{~m}^{-1} \mathrm{~K}^{-1}, \quad D_{\mathrm{t}}=1.35 \times 10^{-7} \mathrm{~m}^{2} \mathrm{~s}^{-1} \quad$ (Rahman, 1995). These values were assumed to be true even for poultry subjected to high superheated steam. For jet temperatures greater than $250{ }^{\circ} \mathrm{C}$, the experimental results highlighted no evaporation of condensates on poultry meat. Thus, this period was not modelled, and steam condensation was therefore directly followed by convection heating of the meat surface. There was good agreement between calculated and experimental results when $h_{\text {conv }}=155 \mathrm{~W} \mathrm{~m}^{-2} \mathrm{~K}^{-1} \quad$ and $\quad h_{\text {cool }}=400 \mathrm{~W} \mathrm{~m}^{-2} \mathrm{~K}^{-1}$ (Fig. 9). Differences between these coefficient values and the values for Teflon ${ }^{\circledR}$ suggested a moderate phase change at the surface of the meat. For $T_{\text {steam }} \leqslant 260{ }^{\circ} \mathrm{C}$, surface temperature remained very similar to $T_{\mathrm{eb}}$ throughout the

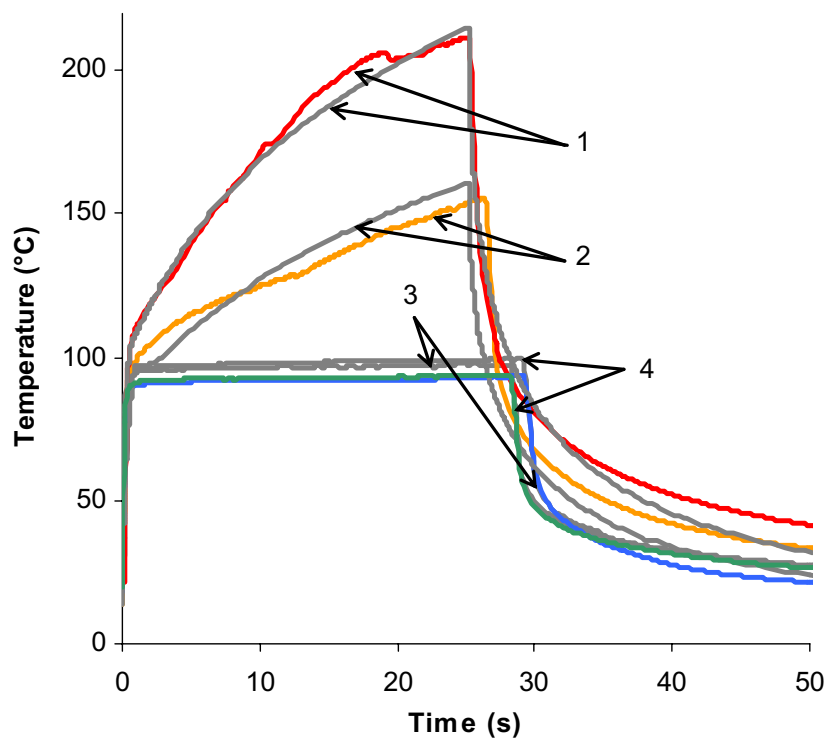

Fig. 9. Comparison between the results measured on poultry muscle (colour curves) and the model predictions (grey curves) $\left(\lambda=0.50 \mathrm{~W} \mathrm{~m}^{-1} \mathrm{~K}^{-1}, D_{\mathrm{T}}=1.35 \times 10^{-7} \mathrm{~m}^{2} \mathrm{~s}^{-1}, h_{\text {cond }}^{0}=774 \mathrm{~W} \mathrm{~m}^{-2} \mathrm{~K}^{-1}\right.$, $h_{\mathrm{eb}}=10 \mathrm{~W} \mathrm{~m}^{-2} \mathrm{~K}^{-1}, \quad h_{\text {conv }}=155 \mathrm{~W} \mathrm{~m}^{-2} \mathrm{~K}^{-1}, \quad$ and $h_{\text {cool }}=400 \mathrm{~W} \mathrm{~m}^{-2}$ $\mathrm{K}^{-1}$ ). For jet temperatures higher than $250^{\circ} \mathrm{C}$, the condensation period is not modelled (i.e. steam condensation is directly followed by convection heating). Surface temperatures measured by the calibrated IR pyrometer on poultry muscle at: $454{ }^{\circ} \mathrm{C}(1), 352{ }^{\circ} \mathrm{C}(2), 200{ }^{\circ} \mathrm{C}(3)$, and $151{ }^{\circ} \mathrm{C}$ (4). (For interpretation of the references to colour in this figure legend, the reader is referred to the conversion of this article.) 
treatment, and calculations were performed with a constant $h_{\mathrm{eb}}$ value of $10 \mathrm{~W} \mathrm{~m}^{-2} \mathrm{~K}^{-1}$ (Fig. 9).

The thermal properties of poultry skin are not precisely known, even at ambient temperature. Poultry skin has a higher lipid content than poultry muscle, and therefore its thermal properties can be bounded by those of poultry muscle and those of pure fat: $\lambda=0.18 \mathrm{~W} \mathrm{~m}^{-1} \mathrm{~K}^{-1}$, $D_{\mathrm{t}}=0.095 \times 10^{-6} \mathrm{~m}^{2} \mathrm{~s}^{-1}$. Lipid and proteins transformations during heating should be different in skin from those occurring in muscle. Thus, the $h_{\text {conv }}$ value used for poultry meat cannot be transposed to skin. The effect of variation in both $h_{\text {conv }}$ and $\lambda$ values on the surface temperature predictions was tested for a constant value of $D_{\mathrm{T}}$ equal to that of Teflon ${ }^{\circledR}\left(D_{\mathrm{T}}=1.04 \times 10^{-7} \mathrm{~m}^{2} \mathrm{~s}^{-1}\right)$. Some calculated results were compared to the measured values given in Fig. 10a under the highest superheated steam temperature, where sensitivity to these parameters was the greatest. Experimental surface temperature varies irregularly during the convective period and cannot be described using the same value of $h_{\text {conv }}$ value. Surface temperature increased rapidly at the beginning of the convective period and then underwent a sudden fall followed by a less rapid increase (Fig. 10a). These kinetics were followed by another similar but less marked fluctuation. These fluctuations are due to the skin cooking. If the chosen conductivity is constant and equal to that of raw poultry meat $\left(0.5 \mathrm{~W} \mathrm{~m}^{-1} \mathrm{~K}^{-1}\right)$, then $h_{\text {conv }}$ would vary between $130 \mathrm{~W} \mathrm{~m}^{-2} \mathrm{~K}^{-1}$, to describe the first rapid increase of surface temperature, and $70 \mathrm{~W} \mathrm{~m}^{-2} \mathrm{~K}^{-1}$ to describe the measurements obtained after $15 \mathrm{~s}$ of treatment. The same predictions can be obtained using the thermal conductivity of Teflon ${ }^{\circledR}(\lambda=0.23$ $\mathrm{W} \mathrm{m} \mathrm{m}^{-1} \mathrm{~K}^{-1}$ ) with $h_{\text {conv }}$ values of $130 \mathrm{~W} \mathrm{~m}^{-2} \mathrm{~K}^{-1}$ and $65 \mathrm{~W} \mathrm{~m}^{-2} \mathrm{~K}^{-} 1$, respectively. The two extreme values of $\lambda$ used in Fig. 10a are not suitable to describe experimental results obtained for lower steam temperature where kinetics are governed by evaporation of condensates. In this case, it is necessary to set very high $h_{\mathrm{eb}}$ values which are not compatible which the values used for Teflon ${ }^{\circledR}$. Thus, an average value is chosen where $\lambda=0.30 \mathrm{~W} \mathrm{~m}^{-1} \mathrm{~K}^{-1}$ making it possible to represent surface temperature kinetics using $70 \mathrm{~W} \mathrm{~m}^{-2} \mathrm{~K}^{-1}$ for $h_{\text {conv. }}$. However, it is clear that other couples of $\lambda$ and $h_{\text {conv }}$ are also able to describe experimental results. Calculations were performed varying $h_{\mathrm{eb}}$ as described previously for Teflon ${ }^{\circledR}$. The best $h_{\mathrm{eb}}$ values were $15 \pm 15 \mathrm{~W} \mathrm{~m}^{-2} \mathrm{~K}^{-1}$ for jet temperatures lower than $250{ }^{\circ} \mathrm{C}$ and $20 \pm 15 \mathrm{~W} \mathrm{~m}^{-2} \mathrm{~K}^{-1}$ for higher jet temperatures (Fig. 10b). The $h_{\text {cool values were higher than on Teflon }}{ }^{\circledR}$ due to surface evaporation with $h_{\text {cool }}=250 \mathrm{~W} \mathrm{~m}^{-2} \mathrm{~K}^{-1}$ for jet temperatures lower than $250^{\circ} \mathrm{C}$ and $h_{\text {cool }}=$ $800 \mathrm{~W} \mathrm{~m}^{-2} \mathrm{~K}^{-1}$ for higher jet temperatures. The $h_{\text {conv }}$ and $h_{\text {cool }}$ values required to describe experimental results on skin are very different from those needed on poultry meat and on Teflon ${ }^{\circledR}$. This difference cannot be explained by variations in thermal properties alone, which therefore indicates that on skin surface, phase changing and other cooking phenomena are very important since they greatly affect heat-mass transfers.
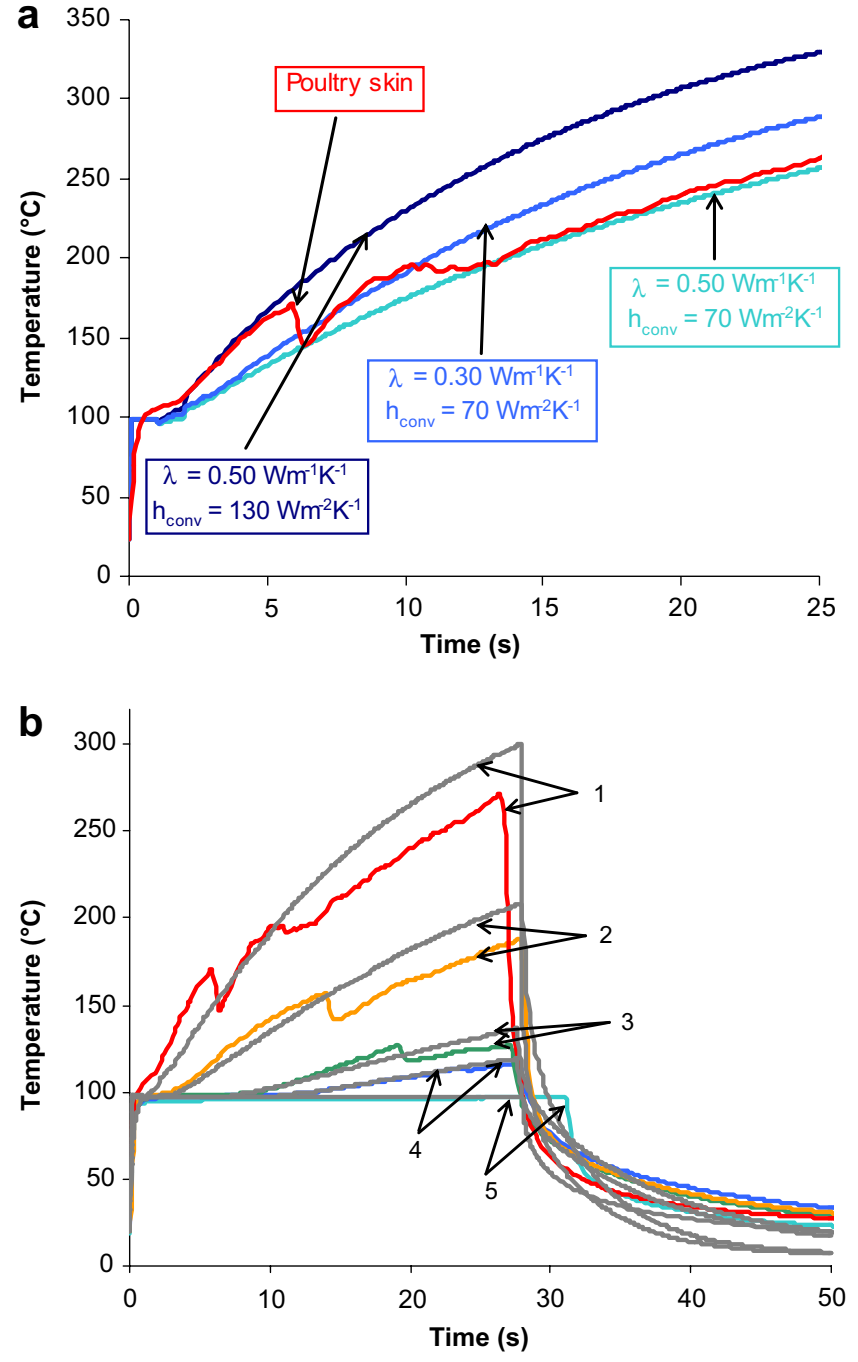

Fig. 10. Comparison between results measured on poultry skin and the model predictions: (a) details of predictions for the highest jet temperature where sensitivity to $\lambda$ and $h_{\text {conv }}$ is the greatest, (b) complete predictions for all jet temperatures and taking into account droplet evaporation (1): $434^{\circ} \mathrm{C}$, (2) $340^{\circ} \mathrm{C}$, (3) $249^{\circ} \mathrm{C}$, (4) $218^{\circ} \mathrm{C}$, and (5) $151^{\circ} \mathrm{C}$. (a) Different $h_{\text {conv }}$ values were taken to describe fluctuations in surface temperature due to skin cooking. (b) The parameters used for these simulations (grey curves) are: $\lambda=0.30 \mathrm{~W} \mathrm{~m}^{-1} \mathrm{~K}^{-1}, \quad D_{\mathrm{T}}=1.04 \times 10^{-7} \mathrm{~m}^{2} \mathrm{~s}^{-1}$, $h_{\text {cond }}^{0}=774 \mathrm{~W} \mathrm{~m}^{-2} \mathrm{~K}^{-1}, \quad h_{\text {conv }}=70 \mathrm{~W} \mathrm{~m}^{-2} \mathrm{~K}^{-1}$ in all cases with $h_{\mathrm{eb}}=15 \pm 15 \mathrm{~W} \mathrm{~m}^{-2} \mathrm{~K}^{-1}, \quad h_{\text {cool }}=250 \mathrm{~W} \mathrm{~m}^{-2} \mathrm{~K}^{-1}$ for $T_{\text {steam }}<250^{\circ} \mathrm{C}$ and $h_{\mathrm{eb}}=20 \pm 15 \mathrm{~W} \mathrm{~m}^{-2} \mathrm{~K}^{-1}, h_{\text {cool }}=800 \mathrm{~W} \mathrm{~m}^{-2} \mathrm{~K}^{-1}$ for higher steam temperatures.

\section{Conclusion}

The heating of a Teflon ${ }^{\circledR}$ surface by a jet of superheated steam can be broken down into three periods: (1) steam condensation, (2) droplet evaporation, and (3) convection heating. When the superheated steam temperature is lower than $260^{\circ} \mathrm{C}$, a short treatment on Teflon ${ }^{\circledR}$ is highly affected by droplet evaporation. This effect gets weaker at higher jet temperatures or under longer treatments, since the relative duration of droplet evaporation decreases. The three periods of heating are clearly visible on poultry skin or 
on muscle covered by skin, while droplet evaporation is not observed on poultry muscle. Condensates are probably absorbed at the surface of poultry muscle and mixed with juice expelled during cooking.

A transfer model was developed to analyse and predict experimental results based on the assumption that steam condenses and evaporates as a film. The model is able to predict temperatures at the surface of Teflon ${ }^{\circledR}$ for jet temperatures higher than $260^{\circ} \mathrm{C}$. The parameters used in the model are in accordance with known results from previous studies and from other literature reports. For lower jet temperatures, the model overpredicts surface temperature because condensate evaporation occurs from droplets and not from a film of water. The film model can be adjusted to mimic droplet evaporation, but this introduces new parameters which cannot be connected to literature studies. The model can be applied to poultry meat and skin, but it has to be fitted to take into account complex phenomena caused by denaturing and cooking that occur during decontamination. In this scenario, the model is useful for analysing and interpolating experimental results, but is no longer satisfactorily predictive.

\section{References}

Arnaud, E., Relkin, P., Pina, M., \& Collignan, A. (2004). Characterisation of chicken fat fractionation at the pilot scale. European Journal of Lipid Science and Technology, 106, 591-598.

Braud, L. M., Moreira, R. G., \& Castell-Perez, M. E. (2001). Mathematical modeling of impingement drying of corn tortillas. Journal of Food Engineering, 50, 121-128.

Chen, Z., Wu, W., \& Agarwal, P. K. (2000). Steam-drying of coal. Part 1. Modelling the behavior of a single particle. Fuel, 79, 961-973.

Devahastin, S., \& Mujumbar, A. S. (2000). Evaluation of some transport and thermodynamic properties of superheated steam: Effects of steam temperature and pressure. Drying Technology, 18(4-5), 1055-1071.

Fyhr, C., \& Rasmuson, A. (1997). Some aspects of the modelling of wood chips drying in superheated steam. International Journal of Heat and Mass Transfer, 40(12), 2825-2842.

Gokhale, S. J., Plawsky, J. L., \& Wayner, P. C. J. (2003). Effect of interfacial phenomena on dewetting in dropwise condensation. Advances in Colloid and Interface Science, 104, 175-190.
Grandas, L., Reynaed, C., Santini, R., \& Tadrist, L. (2005). Etude expérimentale de l'évaporation d'une goutte posée sur une plaque chauffante. Influence de la mouillabilité. International Journal of Thermal Sciences, 44, 137-146.

James, S. J., \& Evans, J. A. (2006). Predicting the reduction in microbes on the surface of foods during surface pasteurisation - The "BUGDEATH" project. Journal of Food Engineering, 76, 1-6.

Kang, H. C., \& Kim, M. H. (1999). Characteristics of film condensation of supersaturated steam-air mixture on a flat plate. International Journal of Multiphase, 25, 1601-1618.

Kim, H. Y., \& Kang, B. H. (2003). Effects of hydrophilic surface treatment on evaporation heat transfer at the outside wall of horizontal tubes. Applied Thermal Engineering, 23, 449-458.

Kondjoyan, A., McCann, M. S., Rouaud, O., Havet, M., Foster, A., Swain, M., et al. (2006). Modelling coupled heat-water transfers during a decontamination treatment of the surface of solid food products by a jet of hot air - II. Validations of product surface temperature and water activity under fast transient air temperature conditions. Journal of Food Engineering, 76, 63-69.

Kondjoyan, A., Rouaud, O., McCann, M. S., Havet, M., Foster, A., Swain, M., et al. (2006). Modelling coupled heat-water transfers during a decontamination treatment of the surface of solid food products by a jet of hot air - I. Sensitivity analysis of the model and first validations of product surface temperature under constant air temperature conditions. Journal of Food Engineering, 76, 53-62.

Martin, H. (1977). Heat and mass transfer between impinging gas jets and solid surfaces. Advances in Heat Transfer, 13, 1-60.

McCann, M. S., Sheridan, J. J., McDowell, D. A., \& Blair, I. S. (2006). Effects of steam pasteurisation on Salmonella typhimurium DT104 and Escherichia coli O157:H7 surface inoculated onto beef, pork and chicken. Journal of Food Engineering, 76, 32-40.

Moreira, R. G. (2001). Impingement drying of foods using hot air and superheated steam. Journal of Food Engineering, 49, 291-295.

Ozisik, N. M. (1994). Finite difference methods in heat transfer. Boca Raton: CRC Press.

Rahman, S. (1995). Food properties handbook. Boca Raton: CRC Press.

Spicher, G., Peters, J., Nürnberg, M., \& Schwebke, I. (2002). Microbiological efficacy of superheated steam. II. Studies involving $E$. faecium and spores of B. xerothermodurans and B. coagulans. International Journal of Hygiene and Environmental Health, 204, 309-316.

Taechapairoj, C., Prachayawarakorn, S., \& Soponronnarit, S. (2006). Modelling of parboiled rice in superheated-steam fluidized bed. Journal of Food Engineering, 76(4), 411-419.

Techasena, O., \& Flick, D. (1995). Surface temperature estimation of solid foods during a surface sterilization. Lebensmittel Wissenschaft und Technologie, 28(4), 419-424. 